\title{
The Construction Cost Conundrum in Africa
}

\subsection{Introduction}

Demand for affordable housing among low- and middle-income households across Africa is high and unmet. Fueled by the continent's rapid urbanization rate and large housing deficits, this demand is projected to grow tremendously in the coming decades. This presents both a huge opportunity and a challenge for the construction industry. The opportunity is to transform the sector in order to respond to this demand, eventually resulting in job creation, industrialization, and ultimately poverty reduction. The challenge stems from the inability of most small and medium-size construction companies to deliver large-scale housing developments, in light of their limited financial and managerial capacity. Moreover, it is noted that there is a mismatch between the supply and the demand for housing.

The high cost of building materials and inefficiencies in the construction process make housing unaffordable for the vast majority of Africans. As formal housing built by real estate developers remains out of reach for the majority of households, self-built housing is the pre- 
ferred and prevalent option for home acquisition. In Cameroon, for instance, 93 percent of the houses are built through owner-driven construction, while in Dakar, Senegal, over 80 percent are self-built. Chaotic urbanization, lack of affordable serviced land, and difficulties in acquiring both an official land title and a construction permit result in the majority of homes being informal. Today, formal housing represents only 10 percent of housing built in African cities. This chapter analyzes the drivers of high construction costs in Africa and provides recommendations for lowering these costs and possible pathways for transforming the sector.

\subsection{The Importance of the Construction Sector}

Although the need for housing construction is important, both residential and nonresidential housing represent a small share in construction spending. The construction sector is undergoing major shifts, with strong demand for construction services fueled by large investments in infrastructure, especially transport and energy. With a huge infrastructure gap to fill—about US $\$ 93$ billion per year-and renewed efforts by national governments and development partners to invest in infrastructure development, the demand for construction is expected to increase further in the coming years.

The value of projects under construction that are worth over US $\$ 50$ million had increased from US $\$ 222$ billion in 2013 to US $\$ 326$ billion by June 2014 (Deloitte 2014). This sharp increase was driven by the rise in the number of megaprojects valued at more than US\$1 billion, although the number of projects actually fell from 322 to 257 . The 2014 distribution by sector shows that transport ( 40 percent) and energy (39 percent) are by far the largest beneficiaries of these construction projects, with real estate representing only 3 percent of the value of construction in the continent.

Construction investment as a share of GDP varies widely across countries, from a low of 1.5 percent in Liberia to a high of 28.5 percent 
in the Republic of Congo, with an average of 10.6 percent and a median of 11.5 percent. Construction spending can also be analyzed as a proportion of total investment. Figure 5.1 shows that in most African countries, the largest share of total investment is directed toward construction spending. Although the median share is 52 percent, 14 countries had shares above 60 percent. This suggests that most countries are largely making efforts to fill their infrastructure gap rather than accumulating machinery and equipment, a move that is important for industrialization.

Although real estate construction is a small share of overall construction spending (3 percent), spending on housing represents a larger share of households' individual consumption expenditures (Fig. 5.2). The average share is 16 percent and varies from a low of 5 percent in Algeria to a high of 33 percent in Comoros. However, these data should be treated with a degree of caution as housing expenditure varies widely between urban and rural areas and will be certainly influenced by levels of urbanization between countries. Spending on housing also depends on housing prices and government transfers to households.

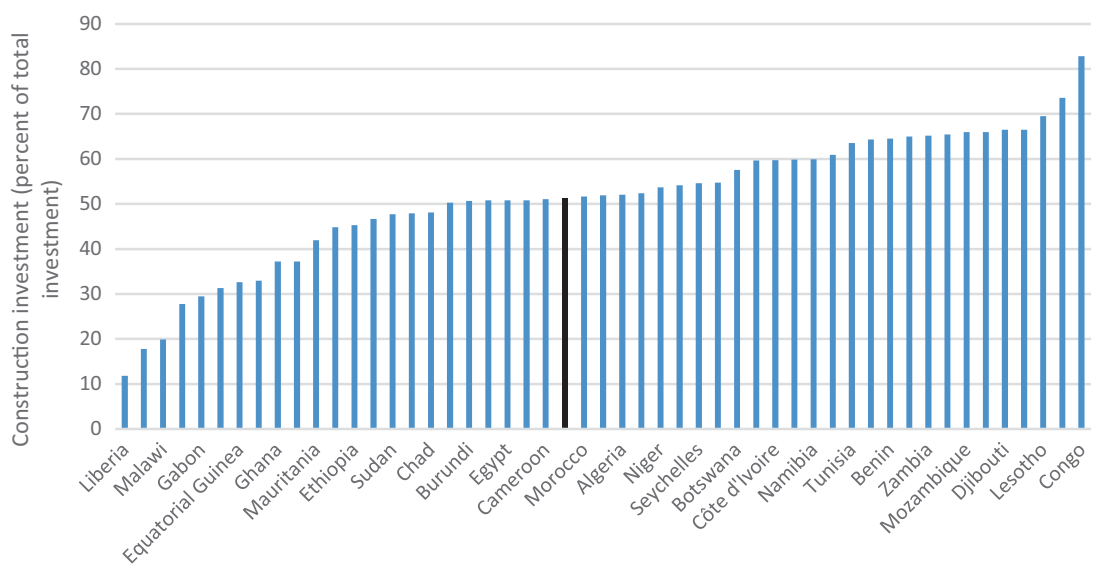

Fig. 5.1 Construction investment as a share of total investment, by country (Source: World Bank, International Comparison Program 2011) 


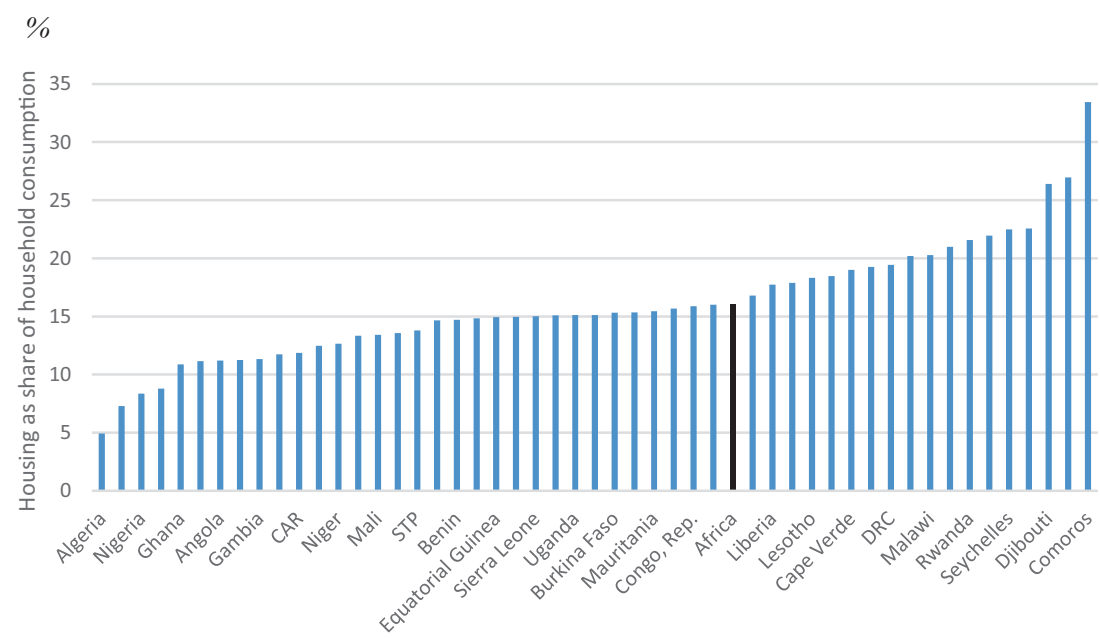

Fig. 5.2 Housing spending as a share of total household spending, by country (\%) (Source: World Bank, International Comparison Program 2011; Note: STP São Tomé and Principe)

\subsection{Housing Construction Costs}

The high construction costs and the lack of affordable land are the two biggest factors affecting housing affordability. As discussed in Chap. 4, Africa's rapid urbanization has generated a scarcity of land across major cities and the unaffordability of well-located plots, resulting in high land prices and urban sprawl. Construction costs are the largest component of home prices in Africa. Data from the South African market apparently suggests that growth in construction costs has been going on for quite some time and the recent trend does not seem to be significantly reversed. This shows the acuity of the affordability issue driven by construction costs in that country.

In Kenya, for instance, construction costs represent 60 percent of overall costs (Fig. 5.3). Land acquisition and infrastructure costs represent another 20 percent. This cost structure contrasts with that of South Africa, where profits and overhead costs are high (31 percent), the bulk and link infrastructure alone represent 23 percent, and construction costs account for 38 percent of the housing costs. This difference suggests that 

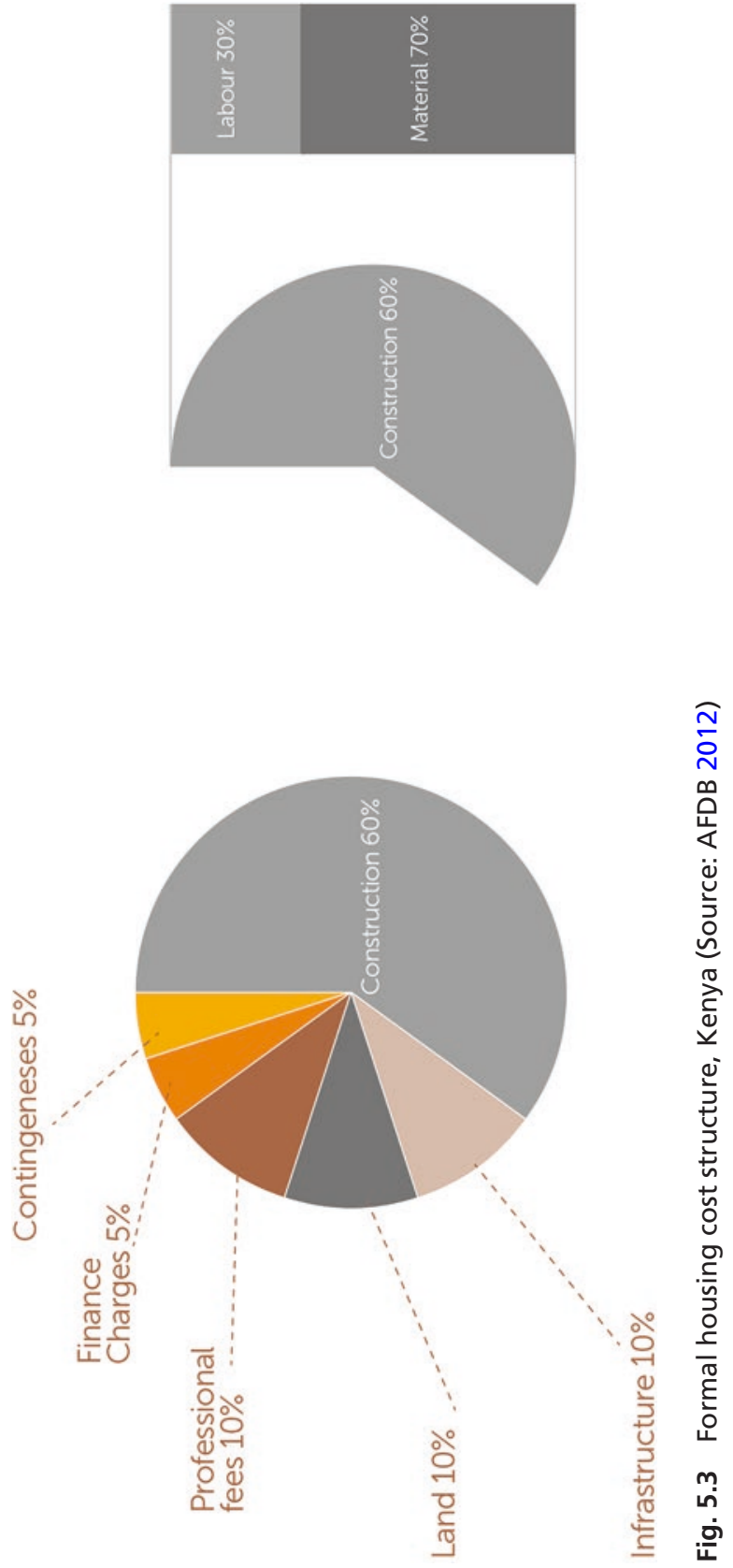

ํํำ

苍

$\ddot{0}$

ํํ

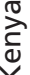

बi

Ð

离

范

드

วิ

믐

ठํำ

m

ํํㄴ 
there may be a room to lower construction costs in Kenya taking South Africa as a benchmark. One possible way to bring construction costs down in Kenya could be through the reduction in the costs of materials.

However, it is worthwhile to note that product differentiation and the lack of unified construction standards make it difficult to gather data and compare housing construction costs across countries. For instance, the cost of a $40 \mathrm{~m}^{2}$ house in a suburb in Nairobi, Kenya, is quite different from a similar-sized house in Niamey, Niger. Moreover, differences in climate, the availability of different types of materials, and varying levels of efficiency among construction companies lead to different costs.

A standard form of cost measurement that seeks to address these differences is the bill of quantities (BoQ) technique. A BoQ provides a detailed view of the necessary inputs, their quantities, and the unit prices for each type of construction project. The project cost is obtained by adding overhead costs to the sum of the product of quantity and unit price for all components, including the hiring of local construction professionals. The implementation of this approach in a large number of countries is thus difficult due to the lack of unified construction standards and the multiplicity of construction materials used across countries. Nonetheless, it remains a feasible and practical approach to consider by governments undertaking standardized housing construction. For instance, the BoQ method is being used by the city of Addis Ababa for the construction of standardized condominiums on a large scale. It enables the city to control costs by supplying materials and managing contracts with a large number of construction companies.

The 2005 International Comparison Program (ICP) introduced a variation of the BoQ approach called the Basket of Construction Components (BOCC), a combination of input and output pricing. Calculating the BOCC involves collecting the prices of basic inputs such as cement and reinforcing steel, as well as the prices of composite components, which are intermediate outputs that are similar across countries. Weights are then used to aggregate the composite components to arrive at the final project costs. To circumvent possible implementation challenges, a simplified input method was used in the 2011 round of the ICP. Data from the ICP 2011 round are summarized in Table 5.1. 
Table 5.1 Construction costs in Africa

\begin{tabular}{|c|c|c|c|c|}
\hline \multicolumn{5}{|c|}{ Price per square meter in US\$ (2011 exchange rates) } \\
\hline & $\begin{array}{l}\text { Single-story, } \\
\text { detached } \\
\text { house, } \\
\text { average } \\
\text { quality, } \\
\text { masonry } \\
\text { (brick or } \\
\text { block) or } \\
\text { timber frame }\end{array}$ & $\begin{array}{l}\text { Two-story } \\
\text { attached } \\
\text { house, mass } \\
\text { market, center } \\
\text { unit in terrace/ } \\
\text { row of four } \\
\text { units }\end{array}$ & $\begin{array}{l}\text { Low-rise } \\
\text { apartment, } \\
\text { mass market, } \\
\text { concrete } \\
\text { frame, brick or } \\
\text { block infill, } \\
\text { walk-up }\end{array}$ & $\begin{array}{l}\text { High-rise } \\
\text { apartment, } \\
\text { average } \\
\text { quality, } \\
\text { concrete } \\
\text { frame, brick } \\
\text { or block infill }\end{array}$ \\
\hline Morocco & 173 & 161 & 161 & 185 \\
\hline $\begin{array}{l}\text { Central African } \\
\text { Republic }\end{array}$ & 181 & 174 & 252 & - \\
\hline Mali & 196 & 223 & 403 & 456 \\
\hline Tunisia & 251 & 299 & 334 & 348 \\
\hline Tanzania & 254 & 382 & 286 & 445 \\
\hline Benin & 278 & 479 & 589 & 747 \\
\hline Kenya & 281 & 360 & 315 & 394 \\
\hline Niger & 306 & 494 & 943 & 627 \\
\hline Burkina Faso & 313 & 493 & 886 & 1250 \\
\hline Ethiopia & 314 & 385 & 402 & 444 \\
\hline Burundi & 317 & 396 & 476 & 515 \\
\hline Egypt & 319 & - & 335 & 302 \\
\hline Malawi & 321 & 449 & 642 & 770 \\
\hline Chad & 350 & 424 & 583 & 848 \\
\hline Gambia & 373 & 543 & 238 & 509 \\
\hline Cameroon & 424 & 371 & 530 & 901 \\
\hline Djibouti & 456 & 439 & 619 & 563 \\
\hline Senegal & 477 & 668 & 689 & 785 \\
\hline Comoros & 537 & 494 & - & - \\
\hline Algeria & 548 & 548 & 466 & 535 \\
\hline Guinea & 549 & 631 & 652 & 694 \\
\hline Ghana & 595 & 554 & 537 & 496 \\
\hline Mozambique & 601 & 1201 & 801 & 1752 \\
\hline Zambia & 613 & 720 & 350 & 613 \\
\hline Nigeria & 617 & 705 & 975 & 1429 \\
\hline Côte d'Ivoire & 626 & 678 & 1007 & 1272 \\
\hline $\begin{array}{l}\text { Congo, } \\
\text { Republic }\end{array}$ & 865 & 989 & 1024 & 1219 \\
\hline Average & 412 & 510 & 557 & 724 \\
\hline Median & 350 & 486 & 533 & 613 \\
\hline
\end{tabular}

Source: World Bank, International Comparison Program 2011 
There are large variations in construction costs across countries, as seen in Table 5.1. The price per square meter for a single-story house varies from a low of US\$173 in Morocco to a high of US\$865 in the Republic of Congo. The variations are large not only across countries but also within regions. The average price per square meter of a single-story detached house is lowest in North Africa (US\$323), followed by East Africa (US\$360), West Africa (US\$428), Central Africa (US\$455), and Southern Africa (US\$512). It is only in North and East Africa that the prices are below the African average of US\$412. Within regions, the lowest variation is within Southern Africa, where the price per square meter for a single-story detached house in Zambia is about 1.9 times than that in Malawi. The largest variation is within Central Africa, where prices range from US\$180 per square meter in the Central African Republic to US $\$ 865$ in the Republic of Congo. The ratio of the highest to the lowest prices is 2.11 in East Africa, 3.16 in North Africa, and 3.19 in West Africa.

\subsection{The Construction Value Chain and Construction Costs}

A detailed analysis of the housing delivery chain is necessary to identify the determinants of high house prices. The first step in the value chain, as shown in Fig. 5.4, is the acquisition of land and provision of bulk infrastructure. As discussed in Chap. 4, rapid urbanization and the lack of urban planning have contributed to soaring land prices in major urban centers across the continent, making well-located land unaffordable to the majority of households. Finance, another critical input of the construction value chain, was discussed at length in Chap. 3 highlighting its contribution to housing prices. Like finance, the government is also present in all stages of the value chain, as a regulator, controller, or producer/ customer. Other important inputs in the construction value chain are design, materials, and labor. The following subsections discuss and analyze each of the main housing delivery value chain input and their contribution to high construction costs. 


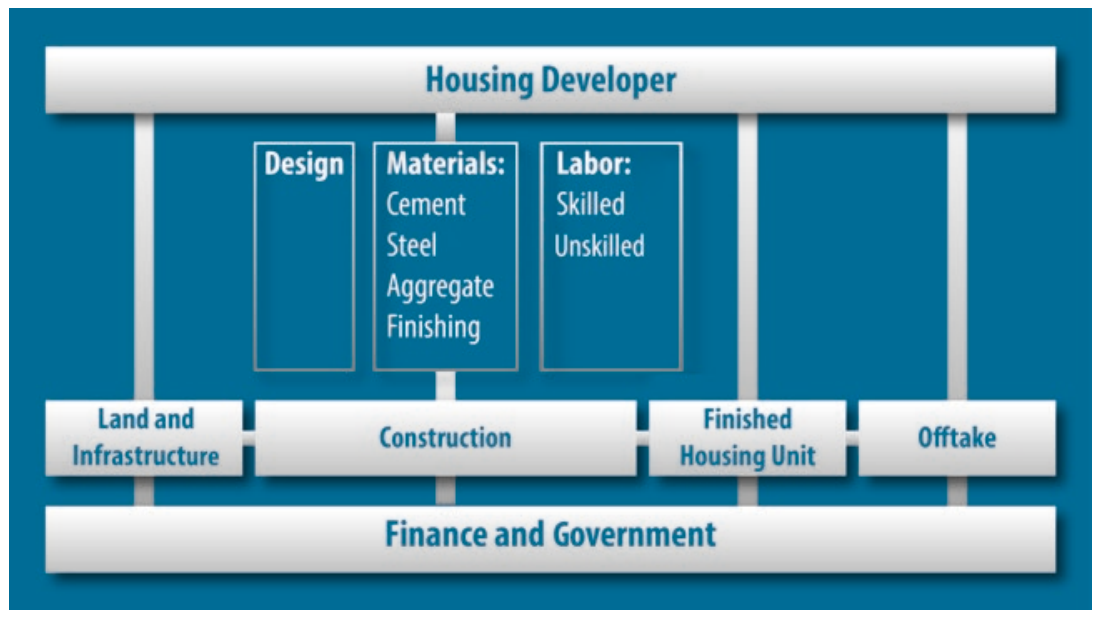

Fig. 5.4 Housing delivery value chain (Source: Author)

\subsubsection{Design}

The value of architectural design is often neglected in the conception of affordable housing development projects. Although the services of an architect may be expensive for a small project of a few housing units, the benefits generally outweigh the costs for large projects. An optimized architectural design can lower construction costs significantly, not only by reducing the quantity of material used but also by minimizing material waste. Simply limiting the number of corners or reducing the number of convex or concave corners reduces construction costs. In addition, using dimensions that are proportional to the standard measures of building materials in the country reduces cutting time and wastage. For instance, flooring work can involve a lot of tile cutting and wastage if the areas are not proportional to the tile sizes available in the market. The 2016 winner of the Pritzker prize in architecture, the Chilean Alejandro Aravena, has demonstrated how good design can be used to build lowcost, functional houses. He has constructed 100 flexible and functional houses in Iquique in Chile costing only US\$7500 per house. For this price, he managed to build houses which are twice the size of the ones the construction industry in Chile could have built $\left(30 \mathrm{~m}^{2}\right)$. 
Phase 1 (2006-2010) of the Ethiopian Integrated Urban Housing Development Program (IUHDP) has used efficient architectural designs extensively to reduce costs. First, the design preparation embraced compact, integrated, and mixed-use settlements (business and residential), consideration of social mix (low- and middle-income households), and density. Building designs included different housing typologies for different income levels to allow for cross-subsidy and cost optimization. Designs were improved continuously through design competitions. The designs were then standardized and facilitated the creation of BoQs that were used in phase 2 of the program. This standardization was very important for phase 2, given that the objectives were much larger than those of phase 1 (Box 5.1).

\section{Box 5.1 Large-Scale Affordable Housing: Ethiopia's Integrated Urban Housing Development Program}

The IUHDP is part of the government's effort to address the housing challenge in Ethiopia, where the housing deficit is estimated at 1 million units. The IUHDP was launched in 2005 as a pilot program, supported by GIZ, to build 5000 housing units annually in Addis Ababa. In 2006, the program was scaled up, with a target to build 396,000 housing units in the first phase of the project (2006/2007-2009/2010) and 231,288 housing units in the second phase (2010/2011-2014/2015).

Given the shortage of land in urban areas and the high costs of infrastructure, the IUHDP decided early on to choose condominium-style housing, despite local habits favoring groundfloor living. New services to facilitate condominium living emerged and preferences changed over time. The program was executed under the form of public-private partnership (PPP). The government, in collaboration with municipality officials, managed procurement of materials and project control, while large private contractors undertook construction. Each large contractor was expected to subcontract 40 percent of the work to micro and small enterprises (MSEs). The centralized bulk purchase of building materials, combined with tax exemptions, contributed to lowering construction costs. The success of the centralized procurement system rested upon the use of standardized designs and the adoption of standardized BoQs. The government also provided land and bulk infrastructure before the start of construction projects.

In response to the shortage of required skills that were identified as a bottleneck early in the planning, the program included a component to build capacity with assistance from GIZ. New graduates from engineering and design schools received skills training, and contractors received both 
skills training and microfinance loans for equipment. This assistance helped create and equip over $4300 \mathrm{MSEs}$, which were involved in different stages of the program from the local production of building materials to finishing works in condominium projects. A national overall skill-upgrading program was implemented at the same time through reforms of tertiary education and technical and vocational education and training (TVET).

Facing rising housing construction prices, the Ethiopian government undertook import substitution strategies that led to a dramatic increase in cement production (see Box 5.3). As a result, cement prices declined by more than 50 percent. Similar efforts to increase the production of steel materials are ongoing.

Although the program continues to experience skill shortages and high costs for some building materials, overall it is a commendable success. As of January 2015, it had built and delivered 329,301 housing units and over 60,000 were under construction. This performance is better than any other large-scale affordable housing program in any sub-Saharan African country, with the exception of South Africa. Moreover, as a result of the laborintensive delivery method of the program, which does not use cranes and heavy machinery, the IUHDP has created 737,256 job opportunities, of which 175,400 arose in the first phase and 561,856 in the second phase.

The most important success factor, cited by the majority of stakeholders, is the government's vision and leadership. Pragmatism, the ability to solve problems as they appear, and a supply chain-driven approach were also important factors that led to the large-scale delivery of affordable housing in Ethiopia.

Source: Based on data gathered in November 2014 fact-finding mission and February 2015 regional workshops; Ermed (2015) and Mekuria (2015).

\subsubsection{Building Materials}

The timely supply of building materials of required specification and quality is a major concern for stakeholders in the construction and housing sector because of its direct impact on construction costs. In other words, affordable housing programs cannot succeed without timely availability of building and construction materials at an appropriate specification, quality, and price. As shown in Fig. 5.3, the cost of materials represents 40 percent of total housing costs in Kenya. This share can be even higher in countries that import the majority of their construction materials. 
Given the huge infrastructure and housing deficits, the abundance of raw materials as well as large construction-related import bills faced by African countries below, it is clear that the construction and building materials sector can be a gateway for Africa's industrialization. In fact, the needs for large-scale affordable housing and infrastructure development programs are so glaring and pressing that the current model based on importation of construction and building materials is not sustainable. The sector is very large: it includes aggregates, cement, iron and steel bars, timber and wood, marble, tiles and stone, electrical and sanitary works, glass, paints and varnishes, electrical lighting, and so on. Some of the subsectors related to the production of these products provide great opportunities for import substitution and job creation. In some countries, it is noticed that the construction and building material sector has already been attractive to large companies.

Aggregates such as sand, gravel, crushed stone, and slag are typically mined in each country by quarrying companies and are not traded across borders. Their prices vary across countries and across cities, depending on the availability of mineral deposits, the cost of transportation, and the efficiency of quarrying companies. Most of other building materials are manufactured products with different degrees of sophistication. Given the limited size and capacity of the manufacturing sector in Africa, most countries import the majority of such products, especially finished products. For instance, in Ethiopia, only one plant makes sanitary products and it has a low production capacity. The exception is South Africa, which has a mature manufacturing sector able to produce most construction products. In the next subsection, we analyze the supply of cement and steel products and discuss how imports of building materials affect house prices.

\subsubsection{Cement Sector}

Africa's cement sector is undergoing unprecedented growth. Heavy investments in infrastructure and housing across the continent are fueling this high demand. Cement consumption Sub-Saharan Africa grew by 6.6 percent in 2014, the highest in the world (Business Day 2015). The Ethiopian Grand Renaissance Dam Project alone is expected to use 10 
million tons of concrete. Despite the recent slowdown in economic growth, investment in infrastructure is expected to increase. This is in part due to the acknowledgment by African governments and their international development partners that the continent needs to address its infrastructure gap for its long-term development.

As a response to this strong demand, cement producers are increasing production capacity at a very rapid pace. Determined to dominate the cement industry in Africa, the Dangote group has invested an estimated US $\$ 5$ billion since 2012, expanding operations to 16 countries (Ecobank 2015). It is estimated that by 2016, the group will have a capacity of 62 million tons per annum (mtpa) with the objective of reaching 81 million tons by 2020 (Adekoya 2015). Dangote's rapid expansion across the continent is pressuring its competitors to increase their capacity. LafargeHolcim, which has a very strong presence in North Africa, is planning to increase its investments in subSaharan Africa, where it is currently the second largest producer. Heidelberg Cement, a German company, has also increased its installed capacity in four African countries within the last two years. Ciments d'Afrique, a Moroccan producer, as well as some Chinese companies and local producers, are also increasing their investments throughout sub-Saharan Africa.

Production capacity in sub-Saharan Africa varies significantly across countries. Ecobank (2015) shows that Nigeria is by far the largest producer, with twice the capacity of the second largest producer, South Africa (Table 5.2). The Nigerian market is dominated by Dangote Cement, which has 68 percent of the market, followed by LafargeHolcim (20 percent) and BUA Cement (12 percent). Spurred by a large-scale housing program (see Box 5.1) and heavy infrastructure investment, Ethiopia's cement production increased from less than 2 million tons a year in the early 2000 s to 15.1 million tons a year in $2015 .{ }^{1}$ The next group of large producers is Kenya, Senegal, and Ghana, with installed production capacity between $6.7 \mathrm{mtpa}$ and $8.9 \mathrm{mtpa}$. Capacity is also increasing in other countries, as Dangote recently opened factories in Cameroon, Tanzania, and Zambia; each country is now producing over 3 mtpa. 
Table 5.2 Installed production capacity in various Sub-Saharan African countries, 2015

\begin{tabular}{ll}
\hline Million tons per annum & \\
\hline Country & Installed capacity \\
\hline Nigeria & 42.7 \\
South Africa & 21.4 \\
Ethiopia & 15.1 \\
Kenya & 8.9 \\
Senegal & 8 \\
Ghana & 6.7 \\
Tanzania & 3.7 \\
Zambia & 3.2 \\
Cameroon & 3.1 \\
Uganda & 2.6 \\
Côte d'Ivoire & 2.5 \\
Angola & 2.5 \\
Benin & 2.1 \\
Mozambique & 1.9 \\
Togo & 1.8 \\
Zimbabwe & 1.7 \\
Guinea & 1.1 \\
Total sub-Saharan Africa & 133.3 \\
\hline
\end{tabular}

Source: Ecobank 2015

Despite the growing production capacity, Africa remains a large importer of cement. Total imports of lime and cement, and fabricated construction materials (excluding glass and clay) by African countries increased from US\$4 billion to US\$5 billion between 2010 and 2014. At the regional level, North Africa, led by Algeria, experienced the largest increase, followed by Central and Eastern Africa (Fig. 5.5). Imports to West Africa have been stable at about US\$1.3 billion, while Southern Africa experienced a 12 percent decline, from US\$311 million to US\$274 million.

Figure 5.6 shows import volumes per country in 2014, as well as the origin of the imports. Algeria is by far the largest importer, with total imports estimated at US\$648 million. Libya and Egypt follow, with imports totaling US\$422 million and US\$307 million, respectively. In sub-Saharan Africa, Nigeria is the largest importer, although imports decreased from US\$426 million in 2010 to US\$280 million in 2014 as a 


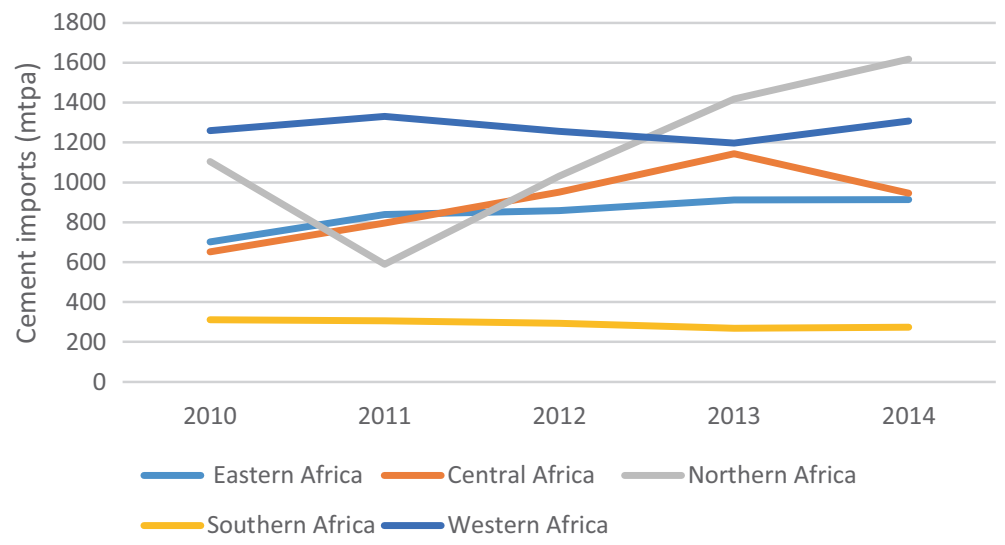

Fig. 5.5 Imports of Lime, Cement, and Fabrication Construction Materials (Excluding Glass and Clay), 2000-2014 (metric tons per year) (Source: UNCTAD)

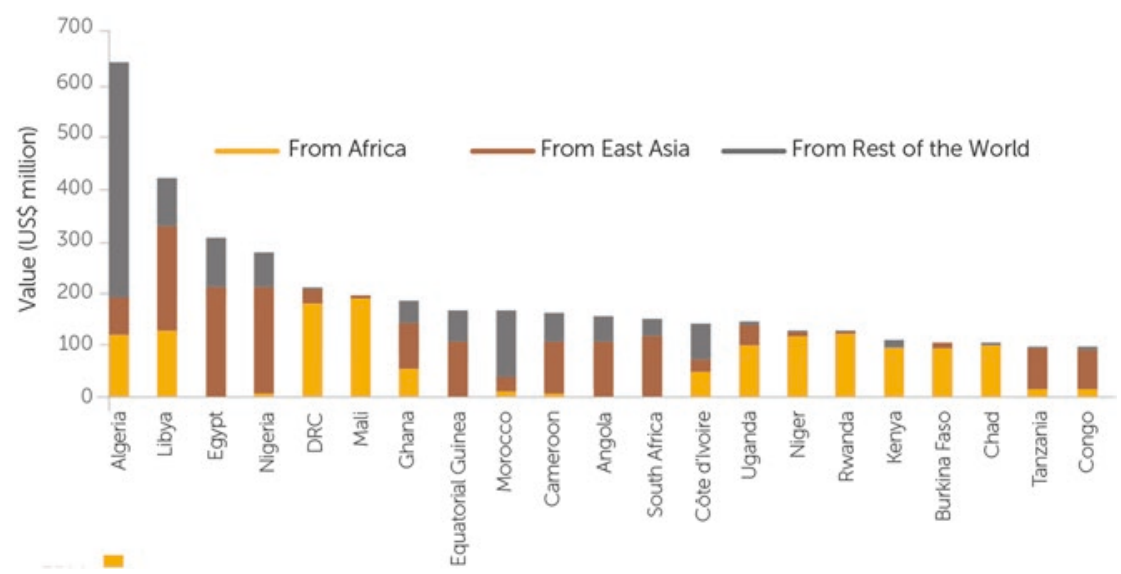

Fig. 5.6 Cement imports by source for top 20 importers, 2014 (US\$ million) (Source: UNCTAD)

result of the rapid increase in production and the adoption of protection policies. It is expected that continued expansion projects and greenfield investments by different actors will make the country self-sufficient in the near future. Following Nigeria, a number of countries in West and Central Africa imported between US\$100 million and US\$200 million 
per year. Overall, these imports contribute substantially to increasing construction costs. They are quite sizeable and alarming knowing that the majority of countries in these regions are low-income countries experiencing more or less substantial budget deficits.

The vast majority of cement imports in Africa originate from East Asia-specifically Indonesia and Pakistan-except in Algeria and Morocco, which, due to their proximity to Europe, have benefited from increasingly competitive European manufacturers. East Asian imports dominate the market in Central and Eastern Africa. However, intraAfrican trade has increased significantly during the last few years. For instance, Burkina Faso, Chad, the Democratic Republic of Congo, Mali, Niger, Rwanda, and Uganda import cement largely from other African countries. This represents a drastic change from 2010, as 17 of 51 African countries more than doubled their volume of imports from other African countries, while their overall imports recorded a smaller increase.

\subsubsection{Steel Products}

In addition to the extensive usage of steel in infrastructure projects, the large quantity of reinforcing steel bars used in Africa's housing construction contribute to the high demand for steel in the continent. However, the size of Africa's steel industry is still very limited. In 2013, for instance, total production of crude steel was estimated at $16.1 \mathrm{mtpa}$ while imports amounted to $25 \mathrm{mtpa}$ (World Steel Association Yearbook 2013). South Africa and Egypt were by far the largest producers in 2013, with production of 7.3 and $6.7 \mathrm{mtpa}$, respectively. Together, both countries produce 93 percent of Africa's crude steel output. Other countries, such as Angola, Kenya, and Nigeria, are trying to increase their production. The biggest importer in 2013 was Algeria with 5.1 mtpa, followed closely by Egypt with $4.2 \mathrm{mtpa}$. Other large steel importers were Nigeria, Morocco, and Kenya, with quantities estimated at $2.2,1.6$, and $1.3 \mathrm{mtpa}$, respectively.

The UNCTAD's trade database had been used to calculate the value of steel imports for all African countries. ${ }^{2}$ Overall, Africa imported US $\$ 14.8$ billion in 2014, which is 19 percent higher than the value of steel imported in 2010. The ranking across countries (Fig. 5.7) shows that in 


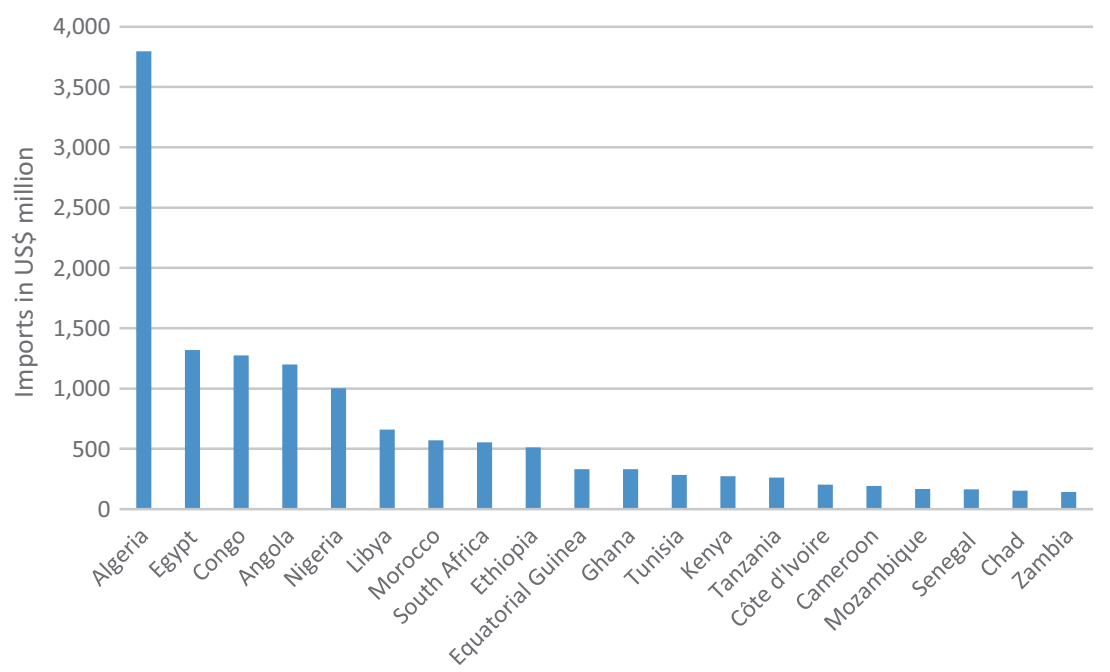

Fig. 5.7 Top 20 steel products importers, 2014 (US\$ million) (Source: UNCTAD)

2014 Algeria alone imported US\$3.8 billion, a quarter of Africa's total imports. Imports of the next three highest ranked-Egypt, Congo, and Angola_came to about a third of Algeria's imports. The figure also shows that the top six importers are among the top oil producers in the continent, reflecting the heavy usage of steel in the oil industry. The fact that Algeria features as the first importer of cement and steel products is not fortuitous, this has a lot do with the ongoing large government infrastructure development and housing programs being implemented in the country. Similar to cement, the importation of steel contributes to increasing construction costs.

\subsubsection{Building Materials Quality Standards}

Improving building material standards is a necessity in most African countries. However, a blind adoption of standards from Europe or the United States would be counterproductive, as environmental and market conditions differ. This is a common challenge for most African countries, particularly in the context of importation of counterfeit goods and production of local building materials. Concerns have been raised in the 
industry about using materials and products that do not comply with national standards.

As response, several African countries have been working on creating and enforcing standards by creating regulatory institutions. Education and training are also vital components in the efforts to improve quality. For example, in 2010, the Ugandan National Bureau of Standards, with assistance from the Swedish International Development Cooperation Agency and TradeMark East Africa, began a five-year quality infrastructure and standards program to establish and strengthen the country's capacity to develop and implement standards.

As part of the efforts to reduce the number of building collapses in Nigeria, the Standards Organization of Nigeria and the Association of Block Molders of Nigeria have reached agreement that a $50 \mathrm{~kg}$ bag of cement should be used to produce only 24 blocks instead of the previous practice of 42 blocks. The Standards Organization then raised molders' awareness of the critical role that cement blocks play in stabilizing buildings and in construction work. The trade association agreed to use the prescribed standards, but this has resulted in a 70 percent increase in the unit price of blocks, from US\$0.70 ( $\mathrm{N} 120-130)$ to US\$1.20 ( 200-250). While this provides a perfect illustration that getting the quality standards right in the construction sector comes with a cost which somehow end up affecting the house prices, it remains that such costs are economically and socially more acceptable than the ones that could be entailed by building collapses due to quality issues.

\subsubsection{Labor}

Labor is a critical input in the construction sector and generally represents 30 percent of overall construction costs. The industry requires both skilled and unskilled labor. Although unskilled labor is widely available, there is an acute shortage of skilled workers, especially well-trained technicians such as electricians, carpenters, plumbers, general construction workers, and, in some countries, engineers and architects. The Kenya Federation of Master Builders, representing 2500 contractors - of which 80 percent are small and medium enterprises (SMEs) — notes that there 
is a large skills gap in the construction sector both in terms of adequacy of human resources and in terms of the productivity and quality of workmanship. This is largely because training costs (about US\$1200) are generally unaffordable for skilled workers, semiskilled workers, and SME contractors and because the curricula of most training institutions are out of touch with industry needs.

Local artisans who construct without respecting building codes dominate the incremental housing construction sector. The lack of the proper professional training and skills to comply with standards locks lowincome households into a cycle of poor-quality, self-built housing. Habitat for Humanity in Kenya (2014) observes that the poor quality is a reflection of the low skills — in both budgeting and building design — of the artisans who influence the procurement process. ${ }^{3}$ This increases the cost of construction and limits the ability to construct decent dwellings.

A challenge facing many African countries is the skills mismatch between the supply and labor demand in many productive sectors. Construction is not an exception. The education systems, which were modeled on European colonial systems, do not respond to local needs. A majority of pupils enrolled in primary and secondary schools end up dropping out before reaching the tertiary level. It is estimated that 90 percent of young people between ages 15 and 24 face a lack of training alternatives and eventually enter the informal sector without proper qualification (UNESCO n.d.). Furthermore, the majority of those who do finish secondary school enroll in general teaching universities whose programs or curricula are not adapted to produce the skills required in the labor market. The 2008 African Economic Outlook notes that, in contrast to sub-Saharan Africa, where enrollment in TVET as a share of total secondary school enrollment is about 5 percent, North African countries have enrollment rates averaging 23 percent. In addition to the limited availability of formal TVET programs in sub-Saharan Africa, progress is hindered by cultural biases in which people perceive such training as the mechanism of enrolling students who failed in the curriculum of general education. Concerted efforts to sensitize youth to their career choices at an earlier age would change such cultural biases. However, while promoting and implementing TVET programs is part of the solution, it is important to note that such TVET programs should be designed in such 
a way that it responds to potential employers' needs, to ensure that students not only get the necessary skills but also find employment upon completing their programs. The difficulty to get skilled labor in the markets and the costs associated to acquiring the adequate skills contribute definitely to increasing construction costs.

\subsubsection{Construction Companies: Predominance of SMEs}

In the housing delivery value chain, construction companies (or contractors) play a critical role, as they use inputs (land, design, construction materials, capital, and labor) to produce housing as output. The ability of these companies to deliver high-quality products at scale and in a costeffective manner will determine whether Africa can reduce the huge housing backlog it faces. However, it is noted that in Africa these construction companies are for the vast majority SMEs with limited technical and financial capacity, unable to build more than a few hundred units per year, except in South Africa and in some North African countries where large local companies have emerged.

SMEs in the construction sector face several constraints. A large number of SMEs operate informally. Their poor governance structures and limited project management skills often lead to execution delays and cost overruns, which ultimately can lead to project failure. Shelter Afrique, a pan-African institution specializing in the provision of debt and equity financing to housing developers, cites the above-mentioned factors together with the lack of equity as the main drivers of the high risk in the sector.

In addition, low access to finance limits the ability of SME developers to deliver a high number of housing units and to grow. In Kenya, for instance, only 13.4 percent of all credits were allocated to building and construction in 2012 and the average interest rate was about 22 percent. The Kenyan Federation of Master Builders views the access to and costs of finance as a huge constraint for the SMEs in the construction sector. Poor access to finance is due in part to the underdevelopment of the financial sector and in part to the risks and constraints in 
the construction sector (see Chap. 3). This has contributed to making affordability a serious challenge for the SME developers.

Consequently, promoters of large-scale housing projects are often obliged to use foreign companies, particularly Chinese construction firms. Chinese companies can deliver large numbers of housing units at affordable prices. For instance, the CITIC (formerly, the China International Trust and Investment Corporation) Group has been involved in the delivery of several housing programs and infrastructure development in several countries on the continent including Angola, Kenya, and South Africa. This poses the sustainability question, given that Chinese contractors were criticized in the past because of their tendency to import cheap labor from China to do the construction work. In an interview with a Chinese construction company operating in Africa, representatives admitted that most of the skilled workers and managers whom they employ are Chinese (Chen et al. 2009). This situation is changing, as the wages of Chinese workers have been rising in recent years and the companies have started to employ low-skilled workers locally in Africa. Chinese construction companies also import most of their construction materials and equipment from China. Projects with a high share of imports for labor and construction materials have a low impact on the development of local economies. Therefore, it is recommended that African countries should have clear requirements for local content if they want to increase the developmental impact of their projects while delivering the needed housing units.

\subsubsection{Government}

The government intervenes at all stages in the housing value chain. It performs sovereign functions including establishing the legal and regulatory frameworks, carrying out inspections, putting in place a conducive business environment, protecting property rights, leveling the playing field to minimize exclusion, and ensuring laws are enforced. Depending on country context and needs, government can intervene from both the supply (producer) and demand (customer) sides of the housing market, to cater especially for low-income households. However, instead of being 
an enabler, government is often seen as an impediment despite the efforts made. As already discussed at length in Chap. 2, in the construction sector the government has failed to deliver on its mandate. This has in most cases translated into additional construction costs and delays. The first failure of governments in Africa is the lack of effective urban planning. Most countries have failed to update urban plans inherited from colonial times, leaving cities to experience informal growth. The second failure is the adoption of the building codes that do not take into account local realities, as they are mostly copied from colonial powers. Collier and Venables (2013) point out that the British Town and Country Planning Act applied in 1947 to British colonies was maintained after independence. The act set regulations that were inappropriate for African countries, given their levels of income then and even now. For instance, the minimum plot size for Nairobi was set at $253 \mathrm{~m}^{2}$ while in Dar es Salaam it was $500 \mathrm{~m}^{2}$. Given the stringent regulations, most households build outside the formal sector, avoiding the regulations altogether. Even those households who chose to work with the formal construction sector often resort to bribery in order to avoid complying with some aspects of the regulations.

Another area where government failed is in terms of the procedures to get construction permits. The procedures are complicated, long, and costly. The World Bank's 2015 Doing Business Report shows that obtaining a construction permit involves at least 10 steps in Namibia and 27 in Republic of Guinea. The time it takes to navigate all the steps varies from 77 days in Rwanda to 448 days in Zimbabwe, while the costs vary from 0.3 percent of the property value in Botswana to 30.8 percent of the value in Madagascar. This contributes to the high construction costs observed on the continent. Figure 5.7 shows the strong correlation between the time to get a construction permit and the cost of a $40 \mathrm{~m}^{2}$ house. This association is due to the fact that beyond the official costs of the permitting process, delays are costly to construction companies.

Building inspection is the fourth area in which government's failure is adding costs and delays to the construction process. Although it is important to ensure that construction adheres to appropriate building codes, especially relating to safety standards, most governments do not have the capacity to perform those inspections due to a lack of sufficient 
well-trained building inspectors. That situation often leads to delays and an opportunity for corruption. A case in point is South Africa, where the shortage of qualified inspectors for the National Homebuilders Registration Council leads to inspection delays and, hence, increases in costs. The Doing Business Report has started computing building quality control index comprising of six subindices: the quality of building regulations, quality control before construction, quality control during construction, quality control after construction, liability and insurance regimes, and professional certifications indices The index ranges from 0 to 15 with higher values indicating better quality. Data for 2015 shows that 28 of 49 countries in Africa have scores lower than 8 and the average for Africa is 7.58. These are proof of the weaknesses in building quality control in Africa.

\subsection{Reducing Construction Costs}

The high costs of land, bulk infrastructure, and housing construction have made it very difficult and often impossible to provide affordable housing for the majority of middle-income and low-income households. Even though, the shortage of affordable housing is not specific to Africa, it has reached a critical level on the continent. It is clear therefore that finding ways to lower construction costs is imperative to meet the affordable housing demand.

This chapter explores several avenues for delivering affordable housing developments while reducing construction costs and house prices in Africa, including the following: (1) industrialized construction, (2) reducing waste of building materials, (3) process improvements to improve efficiency, (4) local production of building materials, (5) use of alternative building technologies, (6) densification, and (7) capacity building and skills training. This is consistent with the findings of the McKinsey Global Institute (Woetzel et al. 2014) report, which, in a global study addressing affordable housing issues, identified four levers that can narrow the affordability gap ${ }^{4}$ by up to 48 percent. These include unlocking land supply, taking an industrial approach, achieving scale efficiency for operations and maintenance, and reducing the costs of and expanding access to finance. 


\subsubsection{Industrialized Construction}

In order to fill the affordable housing deficit of more than 51 million units and deliver large-scale housing developments, Africa's construction sector needs to undergo an extensive transformation toward industrialization. Industrialization of the housing construction process is often mentioned as a way to cut costs, reduce the time of construction, and produce mass housing. It was used in Europe and the United States after World War II with various degrees of success. For instance, the US Housing Act of 1949 set a goal to construct 810,000 units in six years using industrialized methods; however, owing to political opposition to public housing and racial integration, the program was not very successful, as it reached its goal only in 1969 (Von Hoffman 2000).

\subsubsection{Industrialized Construction: What Is It?}

Industrialization of housing construction involves the use of prefabricated parts, manufactured in plants outside the project site, which are then assembled on-site. The objective of the approach is to save time and costs and to achieve gains in productivity (both capital and labor). Productivity in the construction industry is relatively low and has been falling in both developed and developing countries. The MGI report notes that between 1989 and 2009, while overall labor productivity in the United States increased by a third, in the construction sector it fell by a fifth. Bailey and Solow (2001) note that the economies of scale achieved through large housing developments in the United States and the Netherlands are important in explaining their superior productivity compared with other European countries, where small plots of land are allocated to housing projects. They also note that gaps in scale and managerial abilities explain the difference in labor productivity between the United States and Brazil.

Conventional construction methods that are labor intensive and in which most components are made on-site, often involving a lot of specialization, lead to long construction times and high costs. An estimated 33.4 percent of time is wasted in construction sites in Sweden, 
for example (Josephson and Saukkoripii 2007). A large share of this wasted time involves reworking, waiting, handling interruptions, and inaction. Preparation time also represents a large share-45.4 percent-of the total working time, whereas value adding time represents only 17.5 percent. Conventional methods also lead to material waste, as manufactured materials often need to be cut to fit the customized sizes. Another source of low productivity is the dominance of SMEs with low capital equipment and financial capacity. For instance, of the 163,000 companies registered in the United Kingdom in 1998, the majority employed fewer than eight workers (Construction Task Force 1998). Moreover, the firms retain very few skilled workers, as time between projects varies widely. It is argued in this book that adopting an industrial approach would go a long way to addressing the above-mentioned issues.

\subsubsection{Is Industrialized Construction the Right Approach for Africa?}

The public view of industrialized construction is limited to the use of precast components or systems. However, it is our conviction that it goes beyond that, although there is no consensus on its definition. There is not a unique way of defining or conceptualizing industrialization in the construction sector, and the use of prefabrication ranges from simple structures to complete houses. The definition depends on the objective and whether authors are considering either the process or the product (Zabihi et al. 2012). There is also a large variation in the extent of prefabrication. The objectives and experiences of such industrialization also differ by country. For instance, the definition of the US Department of Housing and Urban Development covers the range from prefabricated components or modules up to complete homes, such as mobile homes. In the United States, prefabrication has not taken off, due partly to geographic barriers and availability of low-cost migrant workers. In Malaysia, the use of industrialized building systems has failed to achieve the government's targets despite its implementation of encouraging policies (Chan 2011). In some developed countries, the goal of industrialization is to substitute 
high-cost labor with capital by increasing the usage of automation and equipment. Obviously, this may not be the type of industrialization one would like to experience in Africa, bearing in mind the need for the continent to take advantage of the demographic dividend while addressing the large youth unemployment. In fact, one of the key developmental challenges of African countries today is how to create jobs for the large shares of unemployed or underemployed youth populations and thus improve the livelihood of African people. This calls for housing construction policies that are biased toward more labor-intensive technologies. Prefabrication of complex structures using automation is thus not a viable option for Africa.

The goal of industrialized construction in Africa could consist in producing at massive scale, in shorter periods of time, at lower costs, while taking into account the countries stage of development and peculiarities, including features such as an abundance of unskilled labor and a shortage of capital. In so doing, it is important to ensure that housing and construction policies are integral parts of the country's development policy agenda.

Taking a value chain approach will improve the productivity of the sector and its ability to deliver affordable housing at scale. Moreover, given the role played by SMEs in African economies and their strong presence in the construction sector, industrialization of construction should be seen as a business opportunity for SMEs. In fact, the range of prefabricated materials is large, and simple structures can be made by SMEs with less capital intensity. Using simple and less bulky components makes installation less capital and skill intensive, and therefore could be delivered by SMEs. Indeed, complex components require high skills for installation. In Sweden, some prefabrication companies have failed because they created systems that require low tolerance in the installation process (Malmgren 2014).

A successful example of a labor-intensive construction method using prefabricated materials can be seen in Ethiopia. The first phase of the Ethiopian IUHDP trained and equipped MSEs to prefabricate a number of components and supply some materials such as aggregates. As a result, from 2000 to 2006, some 2600 MSEs employing 49,000 workers were created. The MSEs were involved in production activities for a variety of materials: aggregate, precast beams, hybrid composite beams, metal and 
wood, stone, etc. As the volume of construction increased under phase 2, the number of MSEs involved in prefabrication also increased. Phase 2 created 561,856 jobs and built 192,467 housing units between 2010 and January 2015 (see Box 5.1).

The following subsections describe the steps that are necessary in the industrialization process of the construction sector.

\subsubsection{What Does It Take? Standardization is Key}

Prefabrication or precasting of components such as doors, windows, and sanitary elements is already part of housing construction in Africa. However, the lack of standardized dimensions may prevent the production of these components at large scale. For instance, in self-built housing, each house has its own dimensions for the doors and windows, which are then built to order by carpenters. Moreover, housing superstructures are largely built using blocks that are made on-site or purchased from block molders. Therefore, laying brick for external and internal walls takes a large share of time in the building process. This time and the resulting costs can be cut by using prefabricated concrete or other types of panels. Examples in India, Mexico, and South Africa show time savings of 40-50 percent (MGI 2014). However, savings vary widely, from 10 percent to above 50 percent (Malmgren 2014). In South Africa, the use of precast concrete and optimized design has permitted overall cost savings of 25 percent for an affordable housing project (MGI 2014). The cost savings come from shorter project completion periods, which translate into lower labor and financing costs as well as to lower wastage of building materials. In addition to the time and cost savings, the quality of the superstructure can be increased as the concrete is not exposed to the natural environment and as adequate mixes of cement and aggregates are applied. This consideration is especially important during certain seasons, such as winter in temperate areas and the rainy season in tropical countries.

Prefabrication does not benefit only the superstructure and finishing elements; roofing can also benefit. In difficult working conditions, the roof is generally time consuming and costly. In Kenya's self-built housing, roofing costs constitute nearly 50 percent of the total building costs. 
Roofing is ranked first in terms of the building stage that exerts the most financial pressure on self-built housing for low-income households. Often, roofing expenses dictate the size of rooms at the design stage. ${ }^{5}$ Time and costs can be cut significantly using prefabricated roofing components. In the Republic of Guinea, as in most African countries, most of the affordable houses are roofed using corrugated iron sheets. In the past, the sheets were sold in small sizes, requiring a long time to install and the use of a large number of nails. However, it is noted that new producers of these materials in the market offer customized, longer sheets. This reduces the time and costs of roofing while offering higher quality.

For precast concrete to be a competitive alternative to on-site building, the most important requirements for efficient industrial production are standardization, large scale, and good logistics. Standardized sizes and higher-quality components facilitate large-scale production by component manufacturers and decrease the complexity of building processes. They provide the economies of scale necessary to justify large capital investments. Standardization also allows savings in the sense that it provides an opportunity to combine orders and make large-volume purchases. The Ethiopian Integrated Urban Housing Program, for example, uses bulk purchases to reduce the cost of materials.

Standardized component sizes, quality of building materials, and building codes are important not only within countries but also within regional blocs. For instance, an aluminum window manufacturer from Sénégal will not benefit from economies of scale in exporting its products to the Republic of Guinea if window sizes in the two countries are different. As some regions become increasingly more integrated, it is important to set common standards to enable the creation and growth of regional component manufacturers. In other words, industrializing the construction sector should be seen in a wider perspective of regional integration, if one is concerned with benefiting from economies of scale.

It is important to note that some precast components such as standard concrete panels, which are heavy and costly to transport, require high demand in a relatively small area. Clogged roads in poor condition across the continent constitute a significant constraint, which make the establishment of adequate logistics an important prerequisite for precast concrete. If components cannot be delivered on time and at competitive 
prices, the industrialized approach will not deliver on its goals to save time and costs.

Standardization should be introduced early in the process, at the design stage. Architects need to use available standard sizes in their designs in order to avoid multiple changes during construction (MGI 2014). A value chain approach, in which there is close coordination between designers, component suppliers, transporters, and construction companies, is therefore essential (Construction Task Force 1998). Box 5.2 shows how design, prefabrication, and good supply chain management have been used to reduce construction costs in Angola. It appears also from Box 5.2 that the model of Kora Housing is labor intensive at the assembly phase and required basic skills, which favored the employment of local labor, even in rural areas.

\section{Box 5.2 Kora Housing: Lowering Costs Through Industrialized Construction}

Kora Housing is building 40,000 housing units on 16 sites throughout nine provinces in Angola. It provides quality, affordable housing in community settings for the large and growing middle class emerging in Angola, thereby tackling the country's housing shortage, which is estimated at about 2 million units. From March 2012 to June 2014, the company built and sold 15,206 units to Angola's National Housing Fund. It is now well engaged in phase II of the project, which is to develop the next 7500 units.

The concept behind Kora Housing is to adapt construction systems and materials used for the development of urban communities to local reality and needs. To this end, the company developed comprehensive know-how about industrialized construction systems using prefabricated panels of autoclaved, aerated concrete-lightweight concrete panels that incorporate air. These panels, imported from Europe, are green materials that meet European Union standards; they are available in numerous shapes and sizes, allowing for a wide range of construction applications for all types of buildings. Implementation of projects starts with urban planning, including social infrastructure and housing designs, adapted to the local environment. The construction is executed by subcontractors but managed by Kora. The success factors leading to large-scale delivery and lower costs are the following:

- Design: Housing designs enable the standardization of elements and easy supply chain management, with close relationships between the design and supply chain management teams. 
- Supply chain management: Kora manages the entire supply chain, from acquisition, transportation, and distribution to subcontractors. Purchasing is done in high volume through offtake agreements with material manufacturers and bulk agreements with transportation entities.

- Technology: The light weight of the concrete panels requires only small transport equipment; hence, the mobilization and initiation costs of contractors are very low. The technology also allows contractors to work with unskilled local workers who can be trained on-site.

The results of this construction system are 30 percent savings in construction costs and about 40 percent savings in time. Even though it works in remote provinces, Kora Housing is thus able to sell a house at 50-60 percent of market price. Moreover, despite the industrialized approach of the construction system, it is labor intensive; for instance, upon completion, the project is expected to have created 35,000 local jobs (9000 direct and 26,000 indirect).

Source: Based on Kora Housing Process document.

\subsubsection{Process Improvement to Increase Efficiency}

The low productivity in construction is related not only to the fact that production takes place on-site but also to how the production is organized. Poor project scheduling, with excessive sequencing of tasks, and poor management are important determinants of low productivity. Often, projects are executed the same way they have always been, with no effort to improve processes. The adoption of an industrial approach involves learning from process innovations in other industries and adapting them to the needs of the construction industry. Case in point is lean manufacturing and just-in-time production, which have been introduced in other industries with great success. For instance, rigorous project management and implementing techniques such as flowcharts showing all activities on a critical path to completion can reduce project completion times by making optimal use of the resources to perform some of the tasks simultaneously. The flowchart can also be used to make a better estimate of the demand for resources and to serve as a basis for a critical review of tasks. Such a review can lead to optimized processes that can be documented in an operational manual for employee training. Optimized and documented processes can also reduce rework, which is prevalent in construction projects. It is estimated 
that in developed countries, about 30 percent of the time spent on construction is used for rework (Construction Task Force 1998, Josephson and Saukkoriipi 2007).

Although consultants can be used to analyze and improve processes, construction managers are required to have good project management skills and to execute projects on time with the required quality level. However, during our fact-finding missions in Angola, Cameroon, Côte d'Ivoire, Ethiopia, Kenya, and South Africa, the shortage of managerial skills was often cited as a big constraint for scaling up affordable housing delivery. The Ethiopian government, with assistance from GIZ, undertook a capacity-building program to address this issue and other types of skills shortages. Although the situation has improved over the years, this skill shortage is still seen as a constraint in the sector.

\subsubsection{Reducing Waste of Building Materials}

Waste is a common feature in construction projects in both developed and developing countries. The two main types of waste are time and building materials, both contributing to cost overruns. We have already discussed the contribution of time wastage to the low productivity in the sector. Numerous studies have shown that in developed countries at least 10 percent of the costs of building materials are wasted in construction projects (Egan 1998). In Brazil, the wastage is estimated at about 20-25 percent (Bossink and Bouwers 1996). The extent of wastage of building materials in construction projects in Africa is not widely known but anecdotal evidence points to high shares of the total purchased. John and Itodo (2013) found that wastage contributes on average to 21-30 percent of project cost overruns in Nigeria, depending on the type of subcontracting arrangement. Using a case study in River State, Nigeria, Adewuli, and Otali (2013) show that the main factors contributing to the high levels of wastage are poor supervision, material handling, rework contrary to drawings and specifications, design changes, as well as revision and waste from uneconomical shapes. Similar studies conducted in other countries point to the same conclusion (Alwi et al. 2002, for instance, in Indonesia). 
Given that material costs represent an estimated 50 percent of the overall costs of housing construction in most countries, it is clear that reducing waste will have a large impact on house prices. As discussed above, construction costs could be significantly curtailed by minimizing building material waste. In so doing, it is important that countries' rules and regulations related to the standard measures of building materials are enforced. Recognizing this as a major issue, the IUHDP in Ethiopia created an incentive scheme for contractors to minimize waste: the contractor gets 50 percent of the cost of saved materials exceeding the 10 percent agreed level. In addition to cost considerations, construction waste has environmental costs, as its bulky nature means that it occupies space in landfills. Cement is well known as a nonenvironmentally friendly product, its production, manipulation, and use in construction projects do not always comply with the required standards. The waste related to its production and use could entail nonnegligible public health and biodiversity degradation consequences, which can turn up to be fairly costly. The share of construction waste in total solid waste represents 20-30 percent in Australia, 13-15 percent in Finland, 19 percent in Germany, 26 percent in the Netherlands, and 20-29 percent in the United States (Bossink and Bouwers 1996). To the best of our knowledge, reliable estimates for Africa are not available. Moreover, there are indirect environmental costs as energy is used for the production and transport of materials that are later wasted.

\subsubsection{Local Production of Building Materials}

In recent years, the discussion of structural transformation in Africa has highlighted the pattern of labor moving from agriculture into lowproductive services (Bah 2011, AfDB et al. 2015). What is more, subSaharan Africa has been deindustrializing as the contribution of manufacturing to output has declined in several countries, representing on average just 11 percent of output today (AfDB et al. 2015). It has been argued that this pattern of structural transformation leads to low overall productivity and undermines Africa's long-term development (McMillan and Rodrik 2011). 
The need for Africa to undergo substantive structural transformation, which promotes industrialization has become an argument on which most development partners, such as the AfDB, have agreed upon. Moreover, policymakers and analysts are more or less convinced that industrialization should be high in country development policies and strategies. Recent reports from the United Nations Economic Commission on Africa (UNECA) have focused on how Africa can industrialize through trade, by leveraging its commodities (UNECA 2013, 2015). Manufacturing is seen as a catalyst for job creation and economic diversification (UNECA 2015).

In this book, it is argued that housing development in general, and the production of building materials, in particular, can be a channel through which countries could spearhead their industrialization. Producing building materials in Africa will not only create local jobs but also reduce construction costs. As discussed above, the demand for housing and infrastructure are fueling high demand for building materials, such as cement, steel, and finishing products, but this demand is essentially satisfied through imports, mostly from Asia. Interviews conducted during our fact-finding missions indicated that imports of building materials are an important driver of high construction costs, and this is likely to worsen in the near future due to large infrastructure investment programs on the continent. The effects of imports of building materials on construction costs are even more important in landlocked countries. For instance, it is estimated that transport costs represent 40 percent of building materials costs in Kigali, Rwanda.

This section analyzes the extent to which imports of building materials contribute to higher construction costs. Given the lack of data on the amount of building materials used, it is not possible to calculate the share of imports. Moreover, data on construction costs are available for only 27 countries, thereby making it more difficult to apply regression analysis. However, the available data do show that each of the six countries where we conducted fact-finding missions spent about US $\$ 400$ million in 2014 for imports of building materials, supporting the view of stakeholders according to which imports are the main factor explaining the high costs of construction. Figure 5.8 shows that imports and construction costs are 


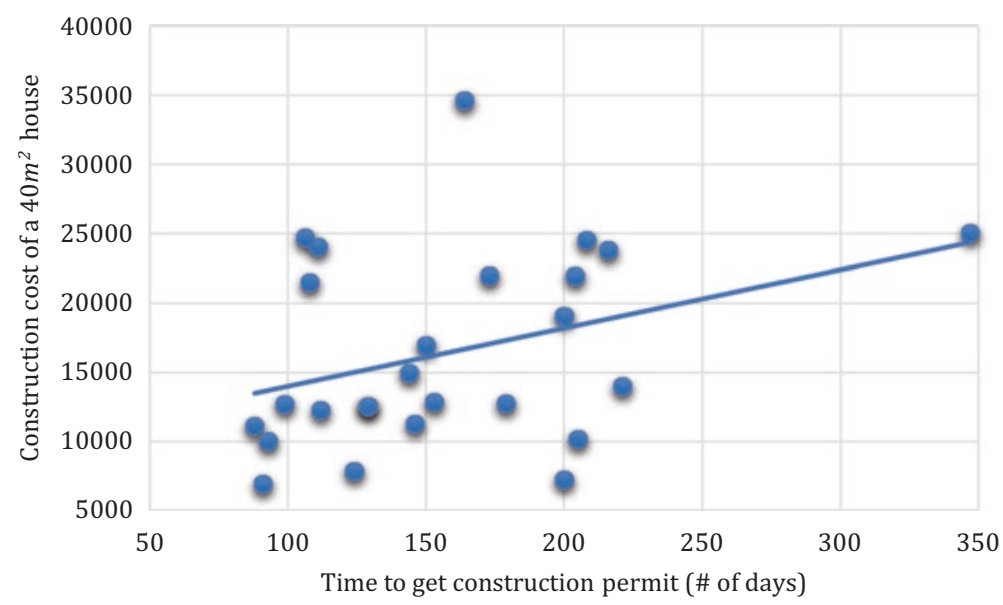

Fig. 5.8 Association between construction permits and construction costs (Source: World Bank Doing Business 2015 and International Comparison Program 2011)

positively correlated, with a correlation coefficient of 0.15 , even without including large importers such as Angola and Libya in the calculation. This suggests therefore that import substitution strategies could play a significant role in reducing the costs of construction (Box 5.3).

The rise in local private-sector production of cement in various countries following the opening of the cement market confirms, at some extent, the observation that high imports as well as monopolistic behaviors contribute to high construction costs. For instance, cement prices in Ethiopia have been reduced by more than half as local production increased (Box 5.3). In Zambia, cement prices dropped by 40 percent between 2014 and 2015, following the opening of the Dangote Cement factory. This prompted accusations that Lafarge had been exploiting its monopoly position in the country (CAHF 2015). In Cameroon, the new Dangote plant commissioned in August 2015 led to a swift decline in cement prices of 15 percent in less than a month. Prices were expected to decline further following the opening of another production plant by Ciments d'Afrique, which would increase the firm's installed capacity from $1.6 \mathrm{mtpa}$ in 2014 to $4.2 \mathrm{mtpa}$. In Tanzania, cement prices were expected to decline by half after the commissioning of a 3 mtpa plant 


\section{Box 5.3 Positive Effects of the Liberalization of the Cement Industry on Costs in Ethiopia}

Until the mid-2000s, only government enterprises could supply cement in Ethiopia. These government factories had a combined capacity of 1.89 million tons per year, which have not been sufficient to meet the increasing demand since 2004. During the period of 2004-2006, the price of cement varied between US\$249 and US\$299 per ton.

In its ongoing efforts to upgrade and expand its infrastructure and housing supply, the government opened the cement market to private investors. As of November 2014, 11 cement factories operated in the country with a combined capacity of over 13 million tons, to supply a total demand estimated at 7 million tons. This excess supply has resulted in a sharp decline in cement prices, by over 50 percent. Today, a ton of cement costs between US\$110 and US\$124. For instance, Derba-produced cement is 20 percent cheaper than government-produced cement, which reduces the overall cost of construction by about 5 percent, according to Derba's chief executive officer.

The opening of the cement market has also brought in the diversity in the cement grades accessible to customers. Derba recently completed a study of low-cost cement that can be used for flooring, wall plastering, fence construction, and the like. It expects to start producing this grade of cement shortly. The company also plans to sell ready-mix concrete in the future. Today, Derba delivers cement directly to all its retailers in Ethiopia using its fleet of 1000 trucks. Some 80 percent of Derba's customers, about 600 retailers, are located within $400 \mathrm{~km}$ of its plant, which facilitates the transportation process. In Addis Ababa, a $50 \mathrm{~kg}$ bag of Derba cement costs US\$10.40, with transport costs accounting for US\$0.62 per bag of cement. Based on this business model, the retailer's profit margin is about US $\$ 0.25$ per bag of cement.

With an excess supply of about 6 million tons of cement, Ethiopia now exports to neighboring countries such as Kenya, South Sudan, and Djibouti. Derba dominates the northern Kenya cement market, with exports of 500,000 tons of cement per month since January 2014. However, Derba has encountered a few challenges in its Kenya expansion strategy. In October 2014, the Kenyan government eliminated the tax-free regime on imported cement and levied a 5 percent surtax on all imports. Moreover, unlike South Sudan and Djibouti, which allow Derba's trucks to deliver cement to its final destination, Kenya does not permit Ethiopian trucks to enter its territory. Cement trucks are required to unload at the border and load the cement bags on Kenyan trucks. The loading and unloading creates delays, which raises the firm's transportation costs. Factoring in the 5 percent surtax, the price for Derba's imported cement is less competitive in cities such as Nairobi. Derba's CEO expects that the ongoing effort to harmonize and standardize customs regulations in the East African Community will facilitate trade across member countries.

Source: Based on an October 2014 meeting with the CEO of Derba Cement. 
by Dangote in October 2015. This evidence supports the argument according to which African countries can make progress toward lowering construction costs by increasing local production of building materials.

Ethiopia and Rwanda are two countries that are undertaking import substitution strategies in the construction materials sector. As discussed earlier, Ethiopia increased its cement production more than sixfold and expects to increase its installed capacity and utilization rates. It is also promoting investments for steel and finishing products. Rwanda, with a growing construction sector worth over US\$500 million, is also promoting investments in the manufacturing of building materials. The Rwandan Development Board (RDB), an investment promotion agency, is promoting investments in steel products, construction glass, and clay materials such as tiles and blocks. In 2011, more than 51 percent of the investment in manufacturing was directed toward the construction materials sector. The RDB expects a further US\$204 million worth of investments in this sector in the coming years (Fig. 5.9).

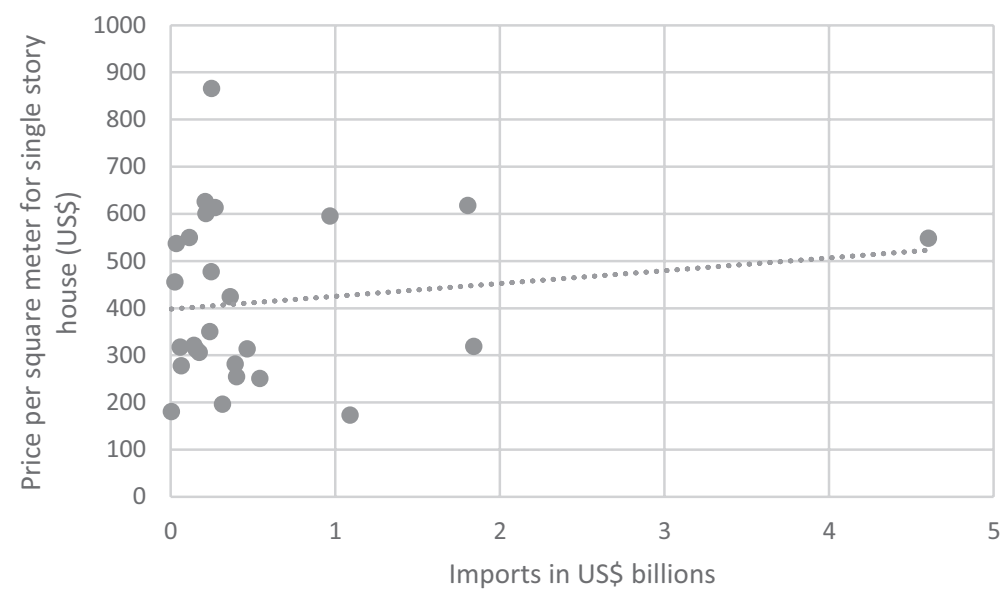

Fig. 5.9 Imports of building materials versus price per square meter, single-story detached house (Source: UNCTAD, World Bank International Comparison Program 2011) 


\subsubsection{Densification for Lower Costs of Urban Infrastructure and Sustainable Cities}

Urban sprawl is costly to countries in all stages of development. A report by the Global Commission on the Climate and the Economy estimates that urban sprawl costs the US economy more than US\$1 trillion per year (Todd 2015). Two direct consequences of urban sprawl are per capita land development and dispersed activities. The secondary impacts are reduced farmland, reduced natural lands, reduced accessibility, higher costs to provide public infrastructure and services, and longer trip distances. These ultimately lead to economic outcomes such as reduced employment in regional business activity, higher food prices and greater dependence on imported food, less clean air, fewer economic opportunities for those who do not have their own transportation means, more traffic congestion per capita, more accidents and pollution, and higher consumer expenditures on fuel (Todd 2015).

As discussed in Chap. 4, it is noted that in Africa the lack of urban planning, high land costs in urban areas, and household preferences for stand-alone housing have led to outward urban sprawl in most cities. In addition to the economic costs discussed above, a direct consequence of this type of growth is the delayed and costly development of urban infrastructure, and hence an increase in housing prices and in slum development. This calls for more dense cities vertically concentrated around main urban infrastructure and business district.

Building compact cities not only reduces the cost of housing construction and ownership, but also leads to sustainable use of resources. Research has shown that compact cities are environmentally more sustainable because of reduced energy use, greater viability of public infrastructure, preservation of agricultural land, and promotion of cultural diversity (CEC 1990, Kenworthy and Labe 1996). A study by PBL Netherlands Environmental Assessment Agency found that densification increases economic productivity and the creation of regional jobs reduces car usage (Nabilek 2011).

Beyond these benefits, densification of African cities will reduce selfbuilt infrastructure, and hence construction costs, and encourage formal development of infrastructure. Indeed, the construction of high-rise 
apartments by housing developers often requires a formal process with adherence to urban plans and building codes. It is, however, noted that in some cities such as Kenya, private individuals in the informal sector are developing five- to seven-story rental apartments. These tenements are creating modern slums, where modern buildings with poor quality of construction lack basic infrastructure and promote overcrowding (Huchzermeyer 2007).

\subsubsection{Alternative Building Technologies}

Most of the building systems in Africa follow building methods used in developed countries, which are largely based on cement and steel construction. UN-Habitat (2013) notes that many of the building codes inherited from the colonial era favor the use of conventional building materials and technologies, consisting mainly of bricks and mortar. However, there are other types of materials, locally available and more environmentally friendly, that can be used for the construction of superstructures. Some of these technologies such as expanded polystyrene panels or cement reinforced mud blocks can speed up the construction process, reduce costs, and mobilize a larger number of workers.

Several factors explain the limited use of alternative building materials. The first is related to cultural biases that make customers reluctant to change. Acquiring or owning a house built with conventional materials is perceived as a symbol of status and wealth, as opposed to acquiring or owning a house built with local materials. For example, despite the superior energy efficiency and lower costs of earth blocks, customers still prefer cement blocks. This misleading perception is shared by architects and engineers, who prefer to use materials they are familiar with. Concerted efforts by governments and the private sector are needed to overcome this barrier and sensitize all stakeholders, starting with the architects, designers, engineers, and customers. In addition to this cognitive behavioral aspect, it is noted that government's regulation can act as a barrier to adopting alternative building technologies. In such cases, appropriate policy reforms should be considered if authorities are concerned with promoting alternative building techniques. Building codes should be 
adapted to local realities (urban vs. rural), promote housing affordability, and favor local production of building materials. A third barrier is technological, as some materials are not adapted to some types of construction. For instance, areas with sandy soils are not appropriate when using earth-stabilized blocks. There is also an issue of quality, given the lack of standards. The final barrier is related to costs, which are high, given the low production capacity of those alternative technologies across the continent. During our fact-finding mission to Cameroon, it was noted that although earth-stabilized blocks are cheaper for a few housing units, the limited production capacity makes them uncompetitive for large-scale housing development. And the lack of access to finance is a key constraint for SMEs involved in production of such technologies.

Recognizing the issues of production capacity and standards, some governments have created agencies to oversee local building technologies. In Cameroon, the Local Material Promotion Authority (commonly known by its French acronym, Mission pour la Promotion des Matériaux Locaux-MIPROMALO) is the government entity tasked with promoting the use of local materials in construction. Its activities are focused on conducting applied research and product development, as well as providing technical assistance to SMEs in the production of local materials. MIPROMALO has identified compressed earth blocks as a viable alternative to cement blocks in many regions of Cameroon. As a result, it built a production plant with the capacity to produce 20,000 compressed earth blocks per day, although its utilization rate is 50 percent because it lacks dryers. Financial and administrative bottlenecks have also inhibited the effectiveness of the institution. Nigeria has an institution with similar objectives called the Raw Materials Research and Development Council. However, this institution has not been effective in fulfilling its mandate as local materials are not widely used.

\subsubsection{Compressed Stabilized Earth Blocks}

One of the most available building materials, used for centuries throughout the world, is soil. Earth construction has been the most effective means for building homes for people in developing countries and has 
shown promising results for an economical solution of the affordable housing problem, reducing costs by at least 25 percent in African countries. In addition, the thermic properties of soil blocks lead to lower internal room temperatures, making air conditioning unnecessary even in hot areas. In some countries such as Sudan, soil is the primary material used for the construction of traditional low-cost dwellings and is well suited to local weather conditions and occupancy patterns. Soil construction is used in 80 percent of urban buildings and over 90 percent in rural areas in Sudan. In other countries, however, there is a cultural stigma surrounding the use of earth blocks as they are associated with poverty. Moreover, poorly constructed and maintained soil buildings can easily discourage the adoption of this technology. Modern knowledge of soil construction techniques such as compressed stabilized earth blocks (CSEB) have been developed but not widely disseminated.

Many housing programs, led by either NGOs or the private sector, have aimed at promoting the use of CSEB. In Angola, Development Workshop (DW) trained clients of Kixi Credito, a housing microfinance institution, on the techniques of CSEB production used in its housing projects. ${ }^{6}$ The results have been a gradual acceptance of the use of CSEB. CSEB is also available in Kenya and promoted by the Kenyan government. The Ministry of Housing established the Appropriate Building Materials and Technology Programme in 2006 to address the high building costs by facilitating the provision of improved and affordable housing in both urban and rural areas. The program purchased CSEB machines from the South African manufacturer, Hydraform, and trained individuals and community-based organizations to make interlocking CSEB. However, poor training and supervision from the government led to the failure of the program as the quality of houses built with the CSEB was poor.

Hydraform produces interlocking blocks using a mixture of soil (90 percent) and cement (10 percent), making the building process faster as well as simpler and more efficient. Moreover, the machines used do not require any specialized skills. These bulletproof and earthquake-resilient blocks have a low carbon footprint and can also be produced on-site. Hydraform's biggest clients are the governments of Nigeria, Rwanda, and Uganda and their technology is present almost everywhere on the continent. 
The company also sells its blocks and machinery to private individuals, NGOs, and other private sector bodies. In Tanzania, the technology is reported to lead to a 30 percent cost saving over conventional brick-andmortar technologies. Hydraform noted the reluctance of some builders to adopt the technology because of their familiarity and dependence on regular bricks-and-mortar systems. Lack of access to funding for budding entrepreneurs and limited capacity among small real estate developers were mentioned as additional challenges in scaling up this technology.

Lafarge has developed a technology of stabilized soil blocks consisting of 5-8 percent cement. This technology is currently being used in Malawi. Lafarge's block manufacturing plant, DuraBric, assists in the design of homes and offers technical assistance. It reports savings of 40 percent over conventional technologies with the use of stabilized soil blocks.

\subsubsection{Expanded Polystyrene Panels}

Expanded polystyrene (EPS) is a lightweight plastic material used in various sectors including construction, packaging, and insulation. EPS panels are constructed by inserting EPS between two metal sheets. The panels are then assembled to form walls or roofs. The technology can reduce construction time and is energy efficient. It is the most common prefabricated building system proposed in Africa. Although ownership costs are estimated to be lower with EPS than with conventional technologies, construction costs depend on how the design is optimized and how much the panels cost. The Expanded Polystyrene Association of South Africa reports construction cost savings of about 30 percent. An additional advantage cited by the industry is the need for only a small crew for installation.

EPS panels are not widely used in Africa, given the limited local production capacity, low performance in noise reduction, and low consumer acceptance of alternative building materials in general. Notwithstanding these drawbacks, the government of Kenya is promoting the use of EPS panels in construction. In 2012, the National Housing Corporation built a factory to manufacture EPS panels based on the expectation that the EPS technology would reduce the costs of construction by up to 30 percent. 
However, the Kenya Federation of Master Builders estimates that the prices of imported panels amount to about half of the prices of the panels produced by National Housing Corporation's EPS plant. Given their anticipated cost saving, EPS panels may be perceived as a solution to building affordable houses in Africa. However, there are a number of reasons to think the contrary. As discussed previously, technology choices should be consistent with the development imperatives of countries, which include job creation among others, and EPS technology is rather capital intensive. For instance, the factory in Kenya employs only 20 people and EPS panel installation is not labor intensive. Moreover, the cost savings do not materialize at project completion, but only after including ownership costs. Another disadvantage is that the production technology uses oil, a nonrenewable fossil fuel, as raw material, which is costly in some countries.

\subsubsection{Other Alternative Building Technologies}

Various other building technologies have been studied and found to be cost-effective and energy efficient. These include cross-laminated timber, bamboo panels, and materials such as composite panels made of elephant grass, coconut husk, and the like. Although these materials are widely available in Africa, the long-term sustainability of its production is not certain. For instance, the continent is experiencing a rapid rate of deforestation so it may not be possible to make sufficient timber panels to meet the affordable housing gap. In addition, manufacturing units are required in order to transform the raw materials into construction panels. Thus, many technologies are still in their laboratory phases and are unlikely to be the solution in the near future.

\subsubsection{Capacity Building and Skills Training}

The discussion earlier highlighted the importance of having the right skills mix throughout the housing supply chain as it entails faster construction with less rework and, hence, results in lower construction costs. Therefore, as African countries seek to scale up housing delivery, capacity building should be an integral part of their programs, as in 
Ethiopia (see Box 5.1). Education programs need to be overhauled in order to give greater importance to TVET. In this process, multilateral organizations such as the AfDB and UNESCO can play an important role. The AfDB should place greater importance on the availability of practical skills in key economic sectors, including construction. This will help solve the problem of high unemployment rates as well as the issue of skills shortage. During our fact-finding missions in different African countries, a number of stakeholders cited skills development and trainings as areas that need support from development partners.

Besides, another potential area that needs support is capacity building for SMEs involved in housing construction. As noted above, SMEs in the sector have limited access to capital, but they also have poor project management skills. Technical assistance programs combined with increased financial access, through either equity or debt, can help improve their capacity to deliver affordable housing. One of the major findings from this book is that by contrast to the general belief, financial assistance alone may not solve the problems of SMEs in the construction sector. Shelter Afrique's experience working with developers has revealed that defaults from SME housing developers in various countries are often driven by poor capacity in project management and marketing. In the same vein, while the economic literature has shown that in developed countries, provision of financial assistance to SMEs improves their probability of survival and growth, evidence has shown that this may not be the case for developing and transition countries (for a review of the literature, see Bah et al. 2011). Housing developers interviewed in various countries across the continent recognized the lack of managerial skills as a key constraint, pointing to the importance of capacity building and skills development.

\subsection{Financing Housing Developers}

A key impediment to the supply of affordable housing in Africa is the lack of finance for developers. Lack of equity to finance for construction and housing development is a major barrier faced by developers, particularly small and medium-size property developers. The financial crisis of 2008 also had a significant impact on the construction industry. In South 
Africa, for instance, the crisis led to the demise of many small-scale developers-most of which lacked the technical and financial strength to weather the economic avalanche. The capacity constraints of developers were further compounded by construction cost overruns and high operation risks. The losses incurred by banks during the crisis spurred them to further tighten their lending requirements, to the detriment of access to finance for many developers. Only a handful of countries-such as Ghana, Morocco, Nigeria, and South Africa-have a well-established class of developers that can develop large-scale housing projects. It is clear from our fact-finding discussions and regional consultation workshops that banks will not provide financing to developers without the necessary risk capital. As discussed in Chap. 3, the lack of market knowledge, including adequate customer credit information systems, by banks may also be a factor contributing to their reluctance to finance developers.

\subsubsection{Presales as a Financing Mechanism for Developers}

According to our discussions with stakeholders, the lack of developer equity accounts for about 20 percent of all project failures. The weak balance sheet of developers further limits their ability to raise risk capital from private investors. In order to cope with this situation, presales or sales on plan, play a significant role in current practice of housing development project financing. Still, even though some financial institutions are willing to provide equity financing for up to 60 percent of the development costs, many developers still cannot bridge the 30 percent equity gap, assuming they can raise 10 percent from presales.

Although presales are an attractive source of finance for developers, they also come with their own challenges, which turn out to be clear limitations for this financing option. First, they reduce the effective demand for affordable housing as they exclude many creditworthy buyers who may not have the resources required in order to pay the upfront house costs. Second, prepurchasers tend to shoulder the credit risks of developers in addition to the risk of not receiving the house as stipulated in the contractual documents. Actually, cases of developer fraud are rampant in many African countries. As a result, countries such as Cameroon and 
Sénégal have enacted condominium laws that secure presales payments and facilitate the mortgaging of housing units prior to construction. However, the effectiveness of such frameworks remains limited, given the lack of buyer awareness and weak enforcement. In Algeria, the Real Estate Guarantee Fund (Fonds de Garantie et de Caution Mutuelle de la Promotion Immobilière-FGCMPI) provides safeguards to buyers that make presales payments for houses (Box 5.4).

A robust regulatory framework and the adoption of legal provisions for registering units in uncompleted development projects are vital for the efficient functioning of pre-sales contracts. The package of securities provided under a prepurchase agreement can include escrow accounts,

\section{Box 5.4 A Guarantee Fund For Real Estate Developers}

The Fonds de Garantie et de Caution Mutuelle de la Promotion Immobilière (FGCMPI) is a real estate guarantee fund established in 1997 under the tutelage of Algeria's Ministry of Housing. The FGCMPI guarantees advance payments made by buyers for both residential and commercial real estate in the event a developer defaults on its contractual commitment. In other words, the guarantee provided by the FGCMPI is a mandatory insurance taken by the developer for the benefit of the property buyer. The fund reimburses advance payments made by buyers in the case of death, fraud, or insolvency of the developer. In the event a private developer abandons an outstanding housing development, the Ministry of Housing through the FGCMPI has the power to form a cooperative to complete the project. In 2013, the fund provided guarantees to 11,350 Logement Social Participatif (LSP) and 10,990 Logement Promotionnel Aidé (LPA) units (assisted housing programs targeting moderate- and middle-income households), as well as 7882 low-income housing units. As of March 2015, 1450 real estate development projects and 135,000 housing units had been guaranteed by the fund, which amounts to approximately DA 450 billion (US $\$ 4.5$ billion).

Before issuing a Certificate of Guarantee to promoters, the fund performs due diligence on the developer examining items such as title, building permits, and the like. Participation in the FGCMPI is mandatory for all developers, who are also required to register in the national database of real estate developers (Tableau National des Promoteurs ImmobiliersTNPI). However, developers have complained about the cumbersome and lengthy application and certification process. In 2013, the fund issued 379 Certificates of Guarantees to developers. However, about 3000 property developers had not registered in the national database as of January 2015, according to government officials. 
FGCMPI membership entails payment of a nominal membership fee, an annual fee that varies according to the size and record of the developer, and a risk-based premium for each insured program-typically 1 percent in the subsidized housing sector and 2 percent for market-based programs. In addition to its role as a guarantee agency, the FGCMPI adds value by (1) screening developers eligible for its coverage, (2) building a rating system, and (3) being the only real estate market observer that gathers information about real estate prices, transaction volumes, and sales trends.

Source: Based on Algerian Ministry of Housing documents.

bank guarantees, insurance, or guarantee funds. Vietnam's residential housing development legislation, which was revised in 2010, provides a good example. The Vietnamese legislation specifically provides requirements for timing and capital mobilization for the development of residential projects. For instance, presales can only start after the house foundation is completed. All in all, managing construction risks is key for attracting private capital to housing development projects in Africa.

\subsubsection{DFI Financing to Support Developers}

Promoting alternative sources of developer finance is crucial for increasing the stock of affordable housing supply in Africa. In Africa, development finance institutions (DFIs) continue to play an important role as market facilitators and a conduit for sustainable private sector financing. Given the development-oriented agenda of DFIs, these institutions are well equipped to assume greater risks such as piloting innovative housing finance instruments on the demand side or mobilizing alternative sources of long-term financing for housing supply. DFIs active in Africa's housing market include Shelter Afrique, the IFC, the National Housing Finance Corporation (NHFC; a wholly owned South African government DFI), and the Overseas Private Investment Corporation (OPIC; a US government DFI). Box 5.5 provides some details on a DFI-sponsored facility to finance developers. Shelter Afrique was established as the AfDB arm in the Housing development sector. As such, the AfDB contributed to the development of the housing sector through its equity participation in Shelter Afrique and equity funds under its management. The huge housing backlogs and the 


\section{Box 5.5 A Construction Finance Facility for Small-Scale Developers and Contractors}

Launched in 1995, the National Urban Reconstruction and Housing Agency (NURCHA) is a construction finance institution that finances developers that are undertaking subsidized and middle-income housing, credit-linked housing, and infrastructure projects in South Africa. Over 85 percent of NURCHA clients are small-scale developers, most of which struggle to access affordable financing. NURCHA finances developers that have little capital and experience to the stage where they become economically sustainable. NURCHA lends directly to experienced developers that have at least three years of experience and audited financial statements. It also finances developers through local financial intermediaries. The credit provided by NURCHA accounts for an estimated 70 percent to 95 percent of the working capital requirements of developers. All credit facilities are short term, no more than 24 months. NURCHA manages several facilities dedicated to affordable housing projects.

The Affordable Housing Facility accounts for 78 percent of NURCHA's total loan book for 2014/2015. This facility provides development finance loans to private-sector developers undertaking affordable housing projects with unit selling prices not exceeding $R 500,000$ (US\$41,000). The average loans granted under this facility over the last 10 years stand at $R 126$ million (US\$10.3 million). In 2014, there was a significant increase in the amount of loans signed, to R 230.7 million (US\$18.9 million). Altogether, 1619 affordable housing units were developed with NURCHA financing in 2014, compared with 1195 in the previous year. Between 2010 and 2014, this facility has delivered 2300 affordable housing units and sites. By contrast, the Infrastructure and Communities Facility is being redesigned after experiencing significant losses. All in all, only eight projects have been financed under this facility.

NURCHA is currently seeking funding to continue its Subsidy Housing Facility, which ended in 2014 after 10 years of support from OPIC, the Soros Economic Development Fund (SEDF), and First National Bank (FNB), one of South Africa's big four commercial banks. This facility provided bridging finance to small- and medium-scale developers, which ensured their active participation in the housing market. The facility was funded directly through NURCHA or a ring-fenced SPV in partnership with OPIC, the SEDF, and FNB. These partners mobilized over R 1336 billion (US\$110 million) in loans for small-scale developers and financed 944 housing projects. The success of this facility was made possible by OPIC's local currency guarantee of R 180 million (US\$14.8 million), which provided loan default guarantees to an equivalent FNB facility for contractors. NURCHA continues to play a vital role in supporting small-scale developers in South Africa.

Source: Based on NURCHA documents. 
pressing needs for housing witnessed by the proliferation of slums and informal settlements, compounded by underdeveloped financial markets, suggest that the possible scope of intervention of DFIs in affordable housing is very large and that more direct players are needed. This explains why AfDB has recently started its direct interventions in the housing sector by supporting mortgage lenders and mortgage refinancing companies. In addition, the failure of Shelter Afrique to meet its promises leaves a large gap for other DFIs to intervene.

In South Africa, the NHFC's pioneering role in using risk enhancement mechanisms has attracted private capital and broadened the range of players involved in the affordable housing market. This has helped spearhead the financing of South Africa's social rental housing market by providing both capacity-building loans to emerging social housing institutions and top-up project finance for social housing delivery. ${ }^{7}$ It also provides both long-term and bridging finance to housing development projects in South Africa. As of December 2016 the NHFC has disbursed R 7 billion (US $\$ 534.5$ million) and has successfully leveraged R 18.6 billion (US\$1.4 billion), a 1:3 leveraging factor.

\subsubsection{Private Equity Funds as an Alternative Financing Mechanism for Developers}

Private equity funds could be another source of patient capital for the continent's developers. It is well known that they play an important role in improving access to long-term finance for African enterprises, especially SMEs. In 2015, Africa-focused private equity funds raised US\$4.3 billion. As the appetite for Africa-focused private equity funds increases, investment activity across the continent has also been on the rise. According to data from the African Private Equity and Venture Capital Association (AVCA), the total deal value in 2015 was US\$2.5 billion, which is a sharp decline from the US\$8.1 billion worth of deals in 2014. As the industry continues to grow, private equity can be an important source of patient capital for the continent's housing market (see Box 5.6 for an example of private equity funds involved in housing development).

Notwithstanding the attractive opportunities for affordable housing investment, private equity has been a historically overlooked asset class in 


\section{Box 5.6 Using Private Equity Funds to Build Platforms That Allow Citizens to Get a Foothold on the Property Ladder}

South Africa, the continent's second largest economy, currently has a housing deficit estimated at 2.3 million housing units, with over 1 million households living in informal settlements, usually with little or no access to water, electricity, sanitation, education, or health facilities. The hardest-hit market segments are the poor and middle-income populations, for which the supply of affordable housing is very limited. As in other African countries, banks and developers in South Africa have historically focused on the upper-end market.

Recognizing the acute housing shortage, International Housing Solutions (IHS) was the first private equity investor to fund the development of residential property in South Africa through its South Africa Workforce Housing Fund. IHS primarily makes equity investments in residential propertiesnew development, conversion, and straight acquisition-that are targeted at filling the gap between the demand for and supply of affordable housing for the "missing middle" market segment.

The major innovation of IHS has been its market-making capacity and its ability to reduce the risk of the construction process in South Africa. IHS identifies developers that are sufficiently strong to warrant its investment and provides them with equity capital to build their capacity. Armed with equity financing from IHS, developers are better equipped to access debt financing from banks, which enables them to be able to withstand challenges in the housing delivery process such as municipal delays in regulatory approvals, issues surrounding the provision and financing of bulk infrastructure, land acquisition, and client over-indebtedness.

The Fleurhof housing project is a classic example of how IHS supports affordable housing and community development. The fund committed $\mathrm{R}$ 105.8 million (US\$8.8 million) to this infill housing development located between Roodepoort and Soweto, two large suburbs close to Johannesburg. Fleurhof is a fully integrated and secure housing project, with one-third of the residential development consisting of Reconstruction and Development Program (RDP) units (i.e., 100 percent government-subsidized housing), while another third consists of affordable houses, and the final third is composed of rental units. Upon completion, the Fleurhof project will have over 9500 housing units, including 8 kindergartens, 4 industrial sites, 5 schools, 14 business centers, and numerous community gardens and play areas (including a skateboard park). This project will accommodate over 30,000 low- and middle-income individuals and help narrow the housing gap in South Africa. Due to the broad base of its residents and the services it provides, Fleurhof won the 2013 Integrated Housing Project of the Year award from the Southern African Housing Foundation. 
What is important is that the Fund has delivered middle-class housing to areas normally associated with poverty, which has supported the cities' socioeconomic integration. The Fleurhof development is a demonstrative case on how private equity can contribute in the delivery of middle-income housing. IHS is contributing to improving property market dynamics in South Africa as it plays a role in changing the housing landscape of the lowmiddle-income property market.

As of December 2014, the fund has fully exited four projects and has returned R 498 million (US\$35.2 million) in cash to investors, or reinvested it in new projects. IHS has also provided opportunities for the finance sector in South Africa by attracting R 2.8 billion (US $\$ 228.6$ million) of project debt financing for its investments. The fund has also contributed in unlocking an estimated R 2 billion (US\$163.7 million) in public-sector funding through infrastructure, subsidies, and government guarantee schemes.

Source: Based on discussions, IHS documents, and interviews with IHS management team.

Africa. According to data from Preqin's real estate online service, eight Africa-focused real estate private equity funds are being raised, with a combined target size of US $\$ 1.8$ billion. This is in sharp contrast to the US $\$ 19$ billion of aggregate capital targeted by 58 Asia-focused real estate private equity funds. The Pan African Housing Fund, Housing Impact Fund South Africa, and Signature Africa Housing Fund are examples of private real estate funds primarily targeting the lower end of the middleincome housing segment in Africa. Affordable housing not only provides private equity investors with an opportunity to generate market returns, it also presents an opportunity to have a significant social impact in Africa. In order to encourage these investors to go further down market, it would be important, for DFIs in particular, to revisit the hurdle rate, or the minimum rate of return on investment required to compensate for the risk involved in low-income housing projects.

\subsection{Conclusion}

This chapter analyzed in detail the housing construction sector in Africa. The emphasis has been on the causes of high construction costs and ways to increase housing affordability. Although comparable data on housing construction costs are available for only a few countries, they show large 
variations in costs across countries. The cost per square meter for a singlestory detached house in the most expensive country (Republic of Congo) is five times the cost in the cheapest country (Morocco). The main causes of high construction costs are the high costs of building materials, at about 50 percent of the construction costs in several countries, and inefficiencies in the building process.

The chapter emphasizes the need to take into consideration the broader development objectives in the choice of solutions aimed at lowering construction costs. Any choice of building technology should consider the challenge of high youth unemployment in the continent. Considering this, along with large housing deficits in most countries, the analysis suggests a labor-intensive industrialized construction approach. This requires the use of precast concrete panels, optimized design, standardized sizes of building components, and a value chain approach. Import substitution and regional integration through the adoption of common standards can lower the costs of building materials. In addition, construction processes need to be improved and wastage of building materials should be reduced in order to improve productivity. Given the financial constraints of housing developers in general and SMEs in particular, alternative financing mechanisms providing equity and loan guarantees are needed to enable the sector the delivery of large-scale housing. Finally, technical and financial assistance to SMEs involved in housing construction and skills training through TVET are recommended in order for the sector to be able to deliver affordable and good-quality housing.

\section{Notes}

1. There is conflicting information about installed capacity in Ethiopia. An article in Global Cement ("Derba Cement Plans US\$300M Expansion," 4 April 2016) quoted the Minister of Industry saying that the country had 18 producers with an installed capacity of $11.2 \mathrm{mtpa}$ as of April 2015. During the scoping mission in November 2014, a number of actors estimated the installed capacity at 13 mtpa.

2. We considered the following subsectors: iron and steel bars, rods, angles, shapes, and sections (SITC code 676); wire of iron or steel (SITC code 678); and tubes, pipes, and hollow profiles, fittings, iron, steel (SITC code 679). 
3. Interview with Marina Yoveva, program development manager for Europe, the Middle East, and Africa, Nairobi, 9 October 2014.

4. The "home purchase affordability gap" is defined as the difference between the price that the average household can afford to pay for a home and the median price of housing on the market.

5. Interview with Ayani for Habitat for Humanity, 2013, by the AfDB and UN-Habitat scoping mission team in Kenya.

6. Angola's first and largest microfinance institution, KixiCasa, offers housing microloans. KixiCredito, which is regulated by the central bank, has 15 branches in nine provinces. DW is KixiCredito's principal shareholder. KixiCasa has about 25,000 clients and provides over US\$30 million in microloans each year.

7. In South Africa, social housing is defined as a rental or cooperative housing unit for low-income persons built by an accredited social housing institution.

\section{Bibliography}

Adekoya, Femi. 2015. Dangote Cement Stakes $\$ 600$ Million on Tanzania Plant. The Guardian News, October 12. http://www.ngrguardiannews.com/2015/ 10/dangote-cement-stakes-600m-on-tanzanian-plant/

Adewuji, T.O., and M. Otali. 2013. Evaluation of Causes of Construction Material

Waste - Case of Rivers State, Nigeria. Ethiopian Journal of Environmental Studies and Management 6 (6). https://doi.org/10.4314/ejesm.v6i6.5S.

AfDB (African Development Bank). 2012. Informal Survey of Developers. Shelter Afrique. Tunis, Tunisia: AfDB

- 2015. Back to Office Report: Scoping Mission for Study on Africa's Housing Market Dynamics. Addis Ababa. Research Division, Development Research Department, 2014 November 1-7.

AfDB, OECD, World Bank, and WEF (African Development Bank,

Organization for Economic Cooperation and Development, World Bank, and World Economic Forum). 2015. The Africa Competitiveness Report 2015. Geneva: World Economic Forum.

AfDB, OECD, and UNDP (African Development Bank, Organization for Economic Co-operation and Development, and United Nations Development Programme). 2015. African Economic Outlook. Regional Development and Spatial Inclusion. https://doi.org/10.1787/aeo-2015-en.

African Business Magazine. 2012. Massive Boost for Building Material Manufacturers, April 23. 
Alwi, S., K. Hampson, and S. Mohammed. 2002. Waste in the Indonesian Construction Projects. In Proceedings of the CIB W107 1st International Conference: Creating a Sustainable Construction Industry in Developing Countries, 11-13 November, Stellenbosch.

Ameh Oko, J., and D.E. Itodo. 2013. Professionals' Views of Material Wastage on Construction Sites and Cost Overruns. Organization, Technology, and Management in Construction 5 (1): 747.

Bah, El-hadj. 2011. Structural Transformation Paths Across Countries. Emerging Markets Finance and Trade 47 (2): 5-19.

Bah, El-hadj M., Josef C. Brada, and Taner Yigit. 2011. With a Little Help from our Friends: The Effect of USAID Assistance on SME Growth in a Transition Economy. Journal of Comparative Economics 39 (2): 205-220. https://doi. org/10.1016/j.jce.2011.03.001.

Bailey, Martin N., and Robert M. Solow. 2001. International Productivity Comparisons Built from the Firm Level. Journal of Economic Perspectives 15 (3): 151-172.

Bossink, B.A.G., and H.J.H. Brouwers. 1996. Construction Waste Quantification and Source Evaluation. ASCE Journal of Construction Engineering and Management 122 (1): 55-60.

Business Day. 2015. Africa in Focus as Lafarge Holcim Launch Globally. Nigeria: Business Day Online.

CAHF (Center for Affordable Housing Finance in Africa). 2015. 2015 Yearbook - Housing Finance in Africa. A Review of Some of Africa's Housing Finance Markets. Parkview: CAHF.

CEC (Commission of the European Communities). 1990. Green Paper on the Urban Environment. European Commission: Brussels.

Chan, T.K. 2011. Comparison of Precast Construction Costs-Case Studies in Australia and Malaysia. In Proceedings of the 27th Annual ARCOM Conference, ed. C. Egbu and E. C. W. Lou. Bristol, September 5-7.

Chen, C., A. Goldstein, and R.J. Orr. 2009. Local Operations of Chinese Construction Firms in Africa: An Empirical Survey. The International Journal of Construction Management 11 (1): 75-89.

Collier, Paul and Anthony J. Venables. 2013. Housing and Urbanization in Africa: Unleashing a Formal Market Process, CSAE Working Paper Series 2013-01. Oxford: Centre for the Study of African Economies, University of Oxford.

Construction Task Force. 1998. Rethinking Construction, Report to the Deputy Prime Minister, UK.

Deloitte. 2014. Deloitte on Africa: African Construction Trends Report 2014. Johannesburg. 
Ecobank. 2014. Commodities, Cement, Middle Africa Insight Series, July 24. . 2015. Commodities, Cement, Middle Africa Insight Series, June 29. Egan, J. 1998. Rethinking Construction: Report from the Construction Task Force. London: Department of the Environment, Transport and the Regions.

Ermed, M.W. 2015. Addis Ababa Integrated Housing Development Program: A Strategy for Urban Poverty Reduction and Sustainable Socio-Economic Transformation, Urban Planning Presentation, Addis Ababa.

Expanded Polystyrene Association of South Africa (EPSASA). n.d. EPS Housing with Social and Economic Benefits. http://expandedpolystyrene.co.za/wp-content/uploads/2014/08/EPS_Housing_social_and_economic_benefits.pdf.

Habitat for Humanity in Kenya. 2014. Interview with Marina Yoveva, Program Development Manager for Europe, Middle East, and Africa, Nairobi, Kenya, October 9.

Hill, Liezel, and Matthew Hill. 2015. Cement Is the New Oil as Africa's Richest Man Takes on Lafarge. Bloomberg News, August 24. http://www.bloomberg. $\mathrm{com} /$ news/articles/2015-08-24/cement-is-the-new-oil-as-africa-s-richestman-takes-on-lafarge

Huchzermeyer, Marie. 2007. Tenement City: The Emergence of Multi-Storey Districts through Large-Scale Private Landlordism in Nairobi. International Journal of Urban and Regional Research 31 (4): 714-732.

IMF (International Monetary Fund). 2008. The World Economic Outlook. Financial Stress, Downturns, and Recoveries. Washington, DC: IMF. Josephson, P.-E., and L. Saukkoriipi. 2007. Waste in Construction Projects, Call for a New Approach. Goteborg: The Centre for Management of the Built Environment, Building Economics and Management Chalmers University of Technology. Kenworthy, Jeffrey R., and Felix B. Laube. 1996. Automobile Dependence in Cities: An International Comparison of Urban Transport and Land Use Patterns with Implications for Sustainability. Environmental Impact Assessment Review 16: 279-308.

Kora Housing. n.d. Company Overview of Concepts and Work Methods. Luanda, Angola: Kora Angola.

Litman, Todd. 2015. Analysis of Public Policies That Unintentionally Encourage and Subsidize Urban Sprawl. Victoria Transport Policy Institute, Supporting Paper Commissioned by LSE Cities at the London School of Economics and Political Science, on Behalf of the Global Commission on the Economy and Climate (www.newclimateeconomy.net) for the New Climate Economy Cities Program. Malgrem, L. 2014. Industrialized Construction: Exploration of Current Practice and Opportunities, Thesis dissertation, Lund University, Lund.

Mathew, Haggai. 2015. Africa in Focus as Lafarge Holcim Launch Globally. Footprint to Africa, July 7. 
McMillan, Margaret S., and Rodrik Dani. 2011. Globalization, Structural Change and Productivity Growth, NBER Working Papers 17143. Cambridge, MA: National Bureau of Economic Research.

Mekuria, T. 2015. Housing Development. The Ethiopian Experience, Paper Presented at the Ministry of Urban Development, Housing, and Construction Regional Consultation Workshop on Housing Market Dynamics in Africa, Addis Ababa, February 17-18.

Nabilek, Kersten. 2011. Urban Densification in the Netherlands: National Spatial Policy and Empirical Research of Recent Developments, Paper Presented at the 5 th International Conference of the International Forum on Urbanism, Singapore, February 24-26.

Polat, G. 2008. Factors Affecting the Use of Precast Concrete Systems in the United States. Journal of Construction Engineering and Management 134 (3): 169-178.

Rwanda Development Board. n.d. Steel Product Manufacturing in Rwanda. http://www.rdb.rw/fileadmin/user_upload/Documents/Manufacturing/2_ Steel_construction_materials_profile.pdf

Sugiharto, A., H. Keith, and M. Sherif. 2002. Waste in the Indonesian Construction Projects. In Proceedings of the First International Conference of $C I B$ W107, "Creating a Sustainable Construction Industry in Developing Countries," South Africa, November 11-13, pp. 305-315.

UNCTAD (United Nations Conference on Trade and Development). Trade Statistics. Online.

UNECA (United Nations Economic Commission for Africa). 2013. Economic Report on Africa 2013: Making the Most of Africa's Commodities: Industrializing for Growth, Jobs and Economic Transformation. Addis Ababa: UNECA.

UNECA (United Nations Economic Commission for Africa). 2015. Economic Report on Africa 2015: Industrializing Through Trade. Addis Ababa: UNECA. UNESCO (United Nations Educational, Scientific, and Cultural Organization). n.d. Technical and Vocational Education and Training (TVET). Equipping Schooled Young People to Succeed in the Workplace. http://www.unesco.org/ new/fileadmin/MULTIMEDIA/FIELD/Dakar/pdf/Info\%20sheet $\% 20$ TVET\%202011.pdf

UN-Habitat. 2013. Affordable Land and Housing in Africa, Adequate Housing Series 076/11E. UN Human Settlements Program, Nairobi.

UN-Habitat and Cities Alliance. 2011. Housing Finance: Ways to Help the Poor Pay for Housing, Quick Guides for Policy Makers 5, UN Human Settlements Program, Nairobi.

Uttam, K. R., R. Madhumita, and S. Subir. 2008. Mass-Industrialized Housing to Combat Consistent Housing Shortage in Developing Countries: Towards an 
Appropriate System for India, In The Proceedings of the World Congress on Housing, "National Housing Programs, New Visions," Kolkata, November 3-7. Von Hoffman, A. 2000. A Study in Contradictions: The Origins and Legacy of the Housing Act of 1949. Housing Policy Debate 11 (2): 299-326.

Ware, Gemma. 2014. Infrastructure: Dangote's Cement Rivals, The Africa Report, September 19.

Woetzel, Jonathan, Ram Sangeeth, Mischke Jan, Garemo Nicklas, Sankhe Shirish. 2014. A blueprint for addressing the global affordable housing challenge, McKinsey Global Institute, available at http://www.mckinsey.com/ insights/urbanization/tackling_the_worlds_affordable_housing_challenge. World Bank. n.d. International Comparison Program 2011. http://siteresources. worldbank.org/ICPEXT/Resources/ICP_2011.html.

- 2013. Measuring the Real Size of the World Economy: The Framework, Methodology, and Results of the International Comparison Program-ICP. Washington, DC. doi:https://doi.org/10.1596/978-0-8213-9728-2.

World Steel Association. 2013. Steel Statistical Yearbook 2013. Brussels: World Steel Committee on Economic Studies.

Zabihi, H., F. Habib, and L. Mirseedie. 2012. Definition, Concepts, and New

Direction of Industrialized Building Systems. KSCE Journal of Civil Engineering 17 (6): 1199-1205.

Open Access This chapter is licensed under the terms of the Creative Commons Attribution 4.0 International License (http://creativecommons.org/licenses/ by/4.0/), which permits use, sharing, adaptation, distribution and reproduction in any medium or format, as long as you give appropriate credit to the original author(s) and the source, provide a link to the Creative Commons license and indicate if changes were made.

The images or other third party material in this chapter are included in the chapter's Creative Commons license, unless indicated otherwise in a credit line to the material. If material is not included in the chapter's Creative Commons license and your intended use is not permitted by statutory regulation or exceeds the permitted use, you will need to obtain permission directly from the copyright holder.

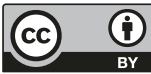

